\title{
Intracellular copper storage and delivery in a bacterium
}

2

3 Jaeick Lee and Christopher Dennison*

4

5 Biosciences Institute, Newcastle University, Newcastle upon Tyne, NE2 4HH, UK. E-mail:

6 christopher.dennison@ncl.ac.uk

\section{Abstract}

10 A family of cytosolic copper ( $\mathrm{Cu}$ ) storage proteins (the $\mathrm{Csps}$ ) are widespread in bacteria. The

11 Csps can bind large quantities of $\mathrm{Cu}(\mathrm{I})$ via their Cys-lined four-helix bundles, and the majority

12 are cytosolic (Csp3s). This is inconsistent with the current dogma that bacteria, unlike

13 eukaryotes, have evolved not to maintain intracellular pools of $\mathrm{Cu}$ due to its potential toxicity.

14 Sporulation in Bacillus subtilis has been used to investigate if a Csp3 can store $\mathrm{Cu}(\mathrm{I})$ in the

15 cytosol for a target enzyme. The activity of the Cu-requiring endospore multi-Cu oxidase BsCotA

16 (a laccase) increases under Cu-replete conditions in wild type $B$. subtilis, but not in the strain

17 lacking $B s C s p 3$. Cuprous ions readily transfer from BsCsp3, but not from the cytosolic copper

18 metallochaperone $B s C o p Z$, to $B s \operatorname{Cot} A$ in vitro producing active enzyme. Both BsCsp3 and

$19 B s \operatorname{Bot} A$ are upregulated during late sporulation. The hypothesis we propose is that $B s C s p 3$

20 acquires and stores $\mathrm{Cu}(\mathrm{I})$ in the cytosol for $\mathrm{BsCotA}$. 


\section{Introduction}

Copper $(\mathrm{Cu})$ is essential for most organisms, but use of this metal ion is associated with significant risks due to its potential toxicity. The availability of $\mathrm{Cu}$ is restricted by the presence of high-affinity sites in both eukaryotes (1) and prokaryotes (2). Import, cytosolic handling, trafficking to different locations, and storage have all been characterised in eukaryotic cells (3). In bacteria, some of these processes are either not thought to occur, or are not yet fully understood. For example, the plasma membrane protein $\mathrm{CcoG}$, which reduces $\mathrm{Cu}(\mathrm{II})$ to the preferred intracellular oxidation state $(\mathrm{Cu}(\mathrm{I}))$ has only recently been identified in bacteria as a cytochrome oxidase (COX) assembly factor (4). The reduction of $\mathrm{Cu}(\mathrm{II})$ prior to import into eukaryotic cells has been known to occur for many years $(3,5)$. Excess $\mathrm{Cu}(\mathrm{I})$ is removed from the cytosol by probably the best-studied component of bacterial $\mathrm{Cu}$ homeostasis; a $\mathrm{Cu}$ transporting P-type ATPase (CopA), which can be assisted by the cytosolic $\mathrm{Cu}$ metallochaperone CopZ (Figure 1a) (3, 6-9). Toxicity has been shown to involve $\mathrm{Cu}(\mathrm{I})$ binding in place of the native metal in cytosolic iron-sulfur (Fe-S) cluster-containing proteins (10), and $\mathrm{Cu}$ catalyses ROS formation $(3,7,8)$. The intracellular damage that $\mathrm{Cu}$ can cause, and the current dearth of intracellular Cu-requiring enzymes (11), has resulted in a prevailing view that bacteria have evolved not to use $\mathrm{Cu}$ in the cytosol $(8,11)$. However, there is no a priori reason why bacteria, like eukaryotes, cannot utilise $\mathrm{Cu}$ in this compartment if mechanisms are available to enable its safe handling, i.e. by ensuring tight chelation and specific delivery. The presence of cytosolic Cu storage proteins (Csps) that can bind large quantities of $\mathrm{Cu}(\mathrm{I})$ with high affinity (1215), provides a possible route for intracellular $\mathrm{Cu}$ use in bacteria.

The Csps were first identified in Gram-negative bacteria that oxidize methane (12). These methanotrophs can possess different Csp homologues, all having many Cys residues lining the cores of their four-helix bundles, enabling the binding of large quantities of $\mathrm{Cu}(\mathrm{I})$ ions (12-14). $\mathrm{A}$ Csp exported from the cytosol (Csp1) can store up to $52 \mathrm{Cu}(\mathrm{I})$ ions per tetramer for the particulate (membrane-bound) methane monooxygenase (pMMO) in the model methanotroph Methylosinus trichosporium OB3b (MtCsp1) (12). MtCsp1 is upregulated (16) at the Cu concentrations required for methane oxidation by $\mathrm{pMMO}$ in switchover methanotrophs, which can use a soluble Fe MMO when $\mathrm{Cu}$ is limiting (17). However, a cytosolic Csp homologue (MtCsp3) is not upregulated with pMMO in M. trichosporium OB3b (16). 

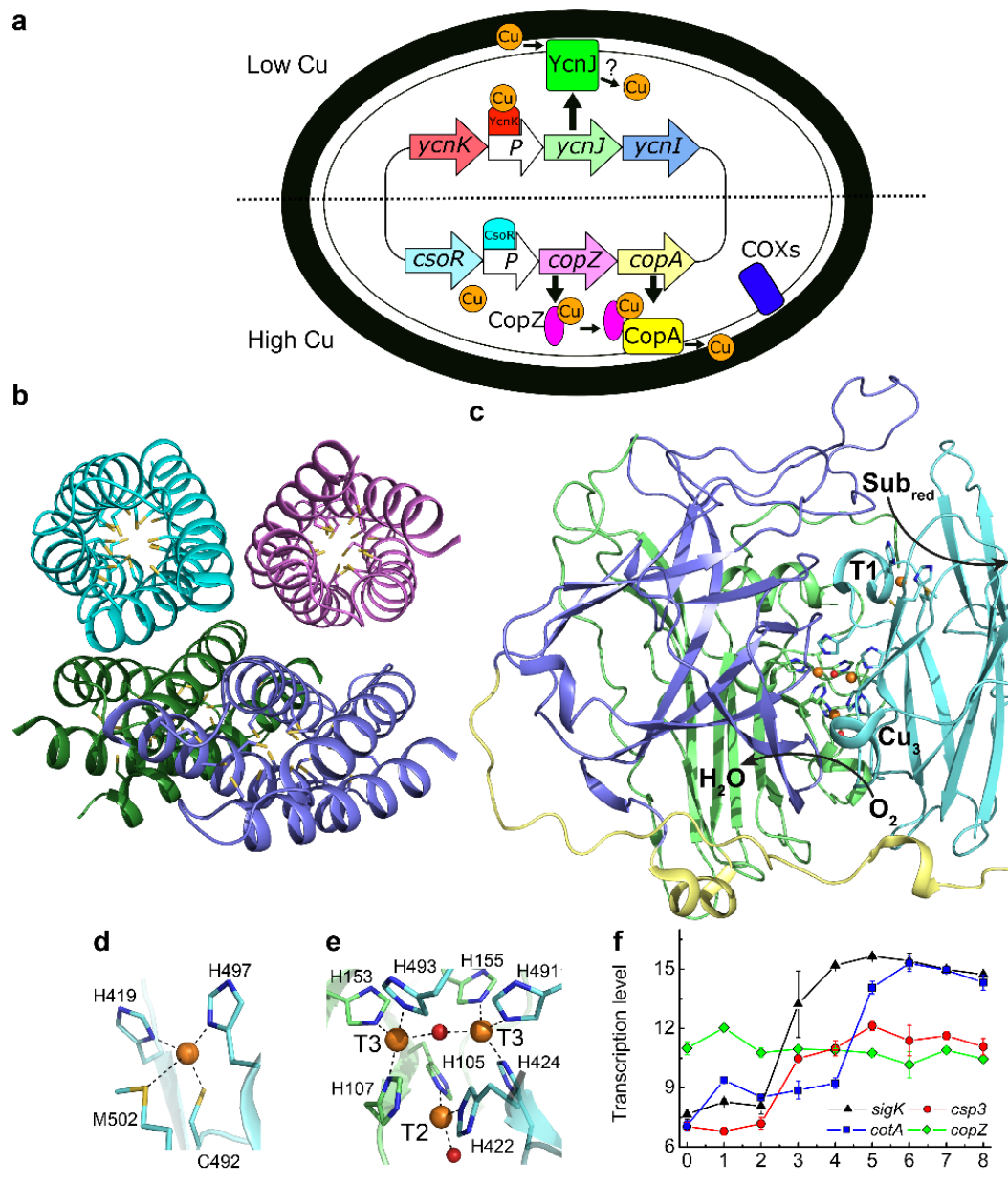

Sporulation time $(\mathrm{h})$

Figure 1. Copper handling, a cytosolic $\mathrm{Cu}(\mathrm{I})$ storage protein, a Cu-requiring enzyme, and their

transcription during sporulation in $B$. subtilis. (a) An overview of $\mathrm{Cu}$ homeostasis in $\mathrm{B}$. subtilis including $\mathrm{Cu}$ (orange circles, oxidation state undefined) export by CopA and CopZ (regulated by CsoR) (19), and import by $\mathrm{YcnJ}$ (regulated by $\mathrm{YcnK})(20,22)$. Ycnl is also membrane bound and binds $\mathrm{Cu}(\mathrm{II})$ in vitro, but its role in $\mathrm{Cu}$ homeostasis is unclear (23). The only currently known Cu-requiring enzymes in vegetative $B$. subtilis cells are two cytochrome oxidases (COXs) located on the plasma membrane $(11,24)$. (b) The crystal structure of $\mathrm{Cu}(\mathrm{I})$-free BsCsp3 (PDB: $5 \mathrm{FIG}$ ), a tetramer of four-helix bundles each with 19 Cys residues pointing into their cores enabling the binding of up to $\sim 20 \mathrm{Cu}(\mathrm{l})$ ions per monomer (13). (c) The crystal structure of the endospore multi-Cu oxidase (a laccase) BsCotA (PDB: 1W6L, (27)) with domains 1, 2 and 3 coloured green, slate and cyan, respectively (the linking regions are yellow). Substrates are oxidized (Subred to Subox) at the T1 Cu centre with electrons passed to the T2/T3 trinuclear $\left(\mathrm{Cu}_{3}\right)$ cluster where oxygen is reduced to water. Detailed views of the T1 Cu site (d) and the $\mathrm{Cu}_{3}$ cluster (e), with the side chains of coordinating residues represented as sticks, $\mathrm{Cu}$ ions as orange spheres and the oxygen atoms of water (bound to the T2 Cu) and hydroxide (bridging the T3 $\mathrm{Cu}$ ions) ligands as red spheres in (c-e). (f) Transcription profiles (29) of the sigK ( $\sigma^{\mathrm{K}}$, which facilitates spore coat protein expression, black triangles), csp3 (red circles), cotA (blue squares) and copZ (green diamonds) genes during sporulation.

The Gram-positive bacterium Bacillus subtilis is an excellent model system for investigating the role of a Csp3, as its Cu homeostasis system is well characterised (Figure 1a) (7, 18-23). The copZA operon (Cu efflux machinery, vide supra) and its Cu-sensing repressor CsoR (7, 18, 
91

101

19, 21) are probably the best-studied components. The membrane protein YcnJ is upregulated under Cu-limiting conditions, controlled by the suggested repressor YcnK $(20,22)$, and has been proposed to play a role in Cu acquisition (Figure 1a). The membrane-anchored $\mathrm{Ycnl}$ is part of the same $(y c n K J I)$ operon and is also regulated by $Y c n K(22)$. The soluble domain of $Y c n l$ binds $\mathrm{Cu}(\mathrm{II})$ in vitro, and this protein has been suggested to function as a $\mathrm{Cu}$ metallochaperone (23). Cytosolic $\mathrm{Cu}(\mathrm{I})$ could be safely stored in $B$. subtilis by the Csp3 homologue (BsCsp3) whose core is lined with 19 Cys residues (Figure $1 \mathrm{~b}$ ), which enable the binding of $\sim 80 \mathrm{Cu}(\mathrm{I})$ ions per tetramer in vitro (13). Overexpressing BsCsp3 in the cytosol of a Gram-negative heterologous host (Escherichia coli) allows growth at otherwise harmful $\mathrm{Cu}$ concentrations, and the protein can acquire $\mathrm{Cu}(\mathrm{I})$ in the presence of both CopA and CopZ (15).

Only two families of Cu enzymes are currently known to be present in B. subtilis; COXs located on the plasma membrane and the multi-Cu oxidase (MCO; a laccase) BsCotA (11, 2427). The latter is an outer spore-coat (endospore) enzyme (28) that possesses the typical type 1 (T1), 2 (T2) and 3 (T3) Cu sites of an MCO (27), which are involved in the catalytic cycle (see Figure 1c-e). It produces a melanin-like pigment thought to provide spores with protection against hydrogen peroxide and UV light $(25,28)$. BsCotA is upregulated during the latter stages of sporulation, as is BsCsp3 (Figure 1f) (29).

BsCsp3 does not provide resistance to Cu toxicity. We have therefore tested the hypothesis that $\mathrm{BsCsp} 3$ safely stores $\mathrm{Cu}(\mathrm{I})$ ions in the cytosol for a Cu-requiring enzyme by investigating the effect of gene deletion on the activity of BsCotA in spores grown under $\mathrm{Cu}$ limiting and replete conditions. The data obtained indicate a direct role for BsCsp3 in ensuring the maximum activity of $B s C o t A$. The ability of $B s C s p 3$ to activate $B s C o t A$ has been confirmed by the in vitro transfer of $\mathrm{Cu}(\mathrm{I})$ between these proteins. A model for how BsCotA acquires $\mathrm{Cu}(\mathrm{I})$ from $\mathrm{BsCsp} 3$ during sporulation is proposed. This is the first example showing that an enzyme can acquire $\mathrm{Cu}$ in the cytosol of a bacterium as well as identifying the partner protein.

\section{Results}

\section{Is BsCsp3 involved in combating Cu toxicity in B. subtilis?}

The presence of a protein with a high capacity for $\mathrm{Cu}(\mathrm{I})$ in the cytosol of $B$. subtilis (12-14) would suggest a role in helping to prevent the problems caused by excess $\mathrm{Cu}(10,15)$. The toxicity of $\mathrm{Cu}$ to bacteria is highlighted by the influence increasing $\mathrm{Cu}$ concentrations in media has on the growth of wild type (WT) B. subtilis (Supplementary Figure 1). At higher Cu levels cells grow extremely slowly, with a very small increase in the absorbance/OD observed only after more than $6 \mathrm{~h}$ at $2 \mathrm{mM} \mathrm{Cu}$, and this coincides with elevated intracellular $\mathrm{Cu}$ concentrations (Supplementary Figure 2). Very similar growth and $\mathrm{Cu}$ accumulation results are obtained for the 
strain ( $\Delta c s p 3$ ) lacking the csp3 gene (Supplementary Figures 1 and 2). These data exhibit an overall likeness to work we reported previously (13), particularly at up to $12 \mathrm{~h}$ growth. However, the response to specific Cu concentrations varies, indicating the amounts of Cu added to media must differ. In the present work we are sure of the Cu concentrations in media, having carefully quantified all $\mathrm{Cu}$ (II) stocks before their addition, and the reported values in the previous study (13) appear to be too high. The growth studies reported herein demonstrate that BsCsp3 is not involved in helping prevent the harmful effects on $B$. subtilis caused by elevated Cu levels. Therefore, the protein does not have a function like eukaryotic Cys-rich metallothioneins (3).

\section{Using sporulation to determine the function of BsCsp3}

The csp3 and $\cot A$ genes are both upregulated (29) at similar stages during sporulation (Figure $1 \mathrm{f})$, and $B s \mathrm{Cot} A$ is the only known Cu-requiring enzyme present in spores. We have therefore studied whether BsCsp3 stores $\mathrm{Cu}(\mathrm{I})$ for BsCotA. This enzyme binds four $\mathrm{Cu}$ ions (Figure 1C-e) and oxidises the laccase substrate 2,2'-azino-bis(3-ethylbenzothiazoline-6-sulfonic acid) (ABTS) in vitro and in spores (26). For WT B. subtilis spores the ability to oxidise ABTS increases approximately two-fold when $50 \mu \mathrm{M} \mathrm{Cu}$ is added to media during sporulation (Figure 2a and Supplementary Figure 3a,b). Incubation with $\mathrm{Cu}(\mathrm{II})$ only enhances the activity of purified WT spores obtained in the absence of added Cu (Supplementary Figure 4 and Table 1), consistent with previously reported data (26). This indicates that unless supplemented, sporulation media does not contain sufficient $\mathrm{Cu}(\sim 0.4 \mu \mathrm{M})$ to fully metallate all of the BsCotA produced. However, the addition of $50 \mu \mathrm{M} \mathrm{Cu}$, a non-toxic concentration, during growth enables $B$. subtilis to obtain enough of the metal to generate only fully $\mathrm{Cu}$-loaded BsCotA in the endospore.

The BsCotA activity of $\Delta c s p 3 B$. subtilis spores grown without added $\mathrm{Cu}$ is similar to that for WT spores produced under the same conditions (Figure $2 b$ and Supplementary Figure $3 c, d$ ). However, unlike for WT B. subtilis, supplementing media with Cu during sporulation has no effect on BsCotA activity for the $\Delta c s p 3$ strain. Similar to the WT data, incubation with Cu only significantly increases the activity of purified $\Delta c s p 3$ spores grown in the absence of added $\mathrm{Cu}$ (Supplementary Figure 4 and Table 1). These results demonstrate that BsCsp3 plays a role in storing $\mathrm{Cu}$ for $\mathrm{BsCotA}$, particularly under $\mathrm{Cu}$-replete conditions. Some BsCotA activity remains for $\Delta \operatorname{csp} 3 B$. subtilis spores, and an alternative mechanism of $\mathrm{Cu}$ transfer to BsCotA must exist, which could also be responsible for the activity observed in the WT strain under Cu-limiting conditions. 

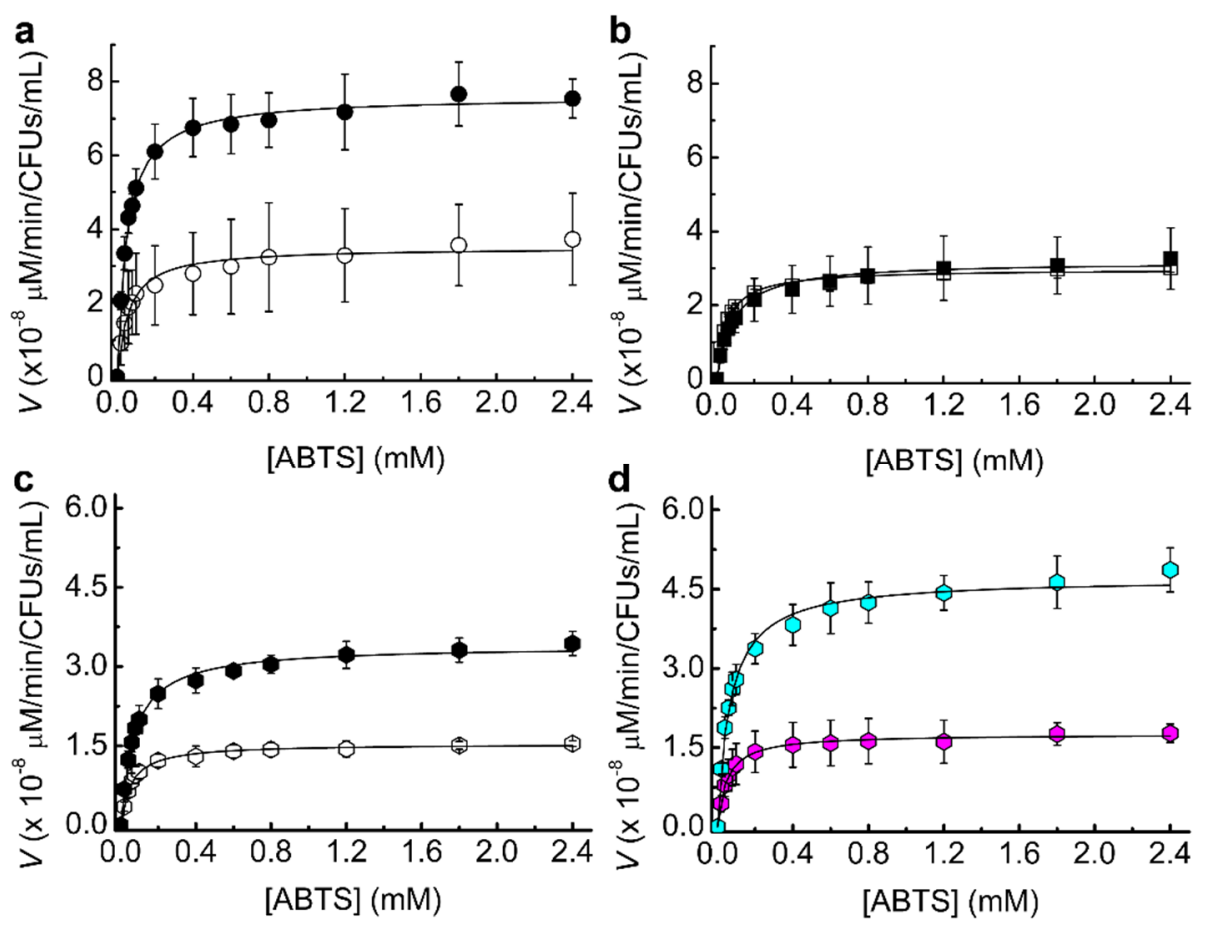

144 Figure 2. The influence of $\mathrm{Cu}$ levels and deleting the csp3 gene on BsCotA activity in B. subtilis.

Michaelis-Menten plots of BsCotA activity for heated purified spores from WT (a), $\Delta \operatorname{csp} 3(\mathrm{~b})$, and the complemented $\Delta c s p 3(c, d)$ strains. Spores $(a, b$ and $c$ ) were produced in Difco sporulation media plus no (open symbols) and $50 \mu \mathrm{M}$ (black filled symbols) added $\mathrm{Cu}\left(\mathrm{NO}_{3}\right)_{2}$. (d) For the complemented $\Delta c s p 3$ strain sporulation was also carried out in the presence of $1 \mathrm{mM}$ IPTG with either no (magenta) or $50 \mu \mathrm{M}$ (cyan) added $\mathrm{Cu}\left(\mathrm{NO}_{3}\right)_{2}$. The plots from which the initial rates for $\mathrm{WT}$ and $\Delta \operatorname{csp} 3 \mathrm{~B}$. subtilis spores were obtained are shown in Supplementary Figure 3. Averages and standard deviations from kinetic measurements in $100 \mathrm{mM}$ citrate-phosphate buffer $\mathrm{pH} 4.0$ using three different sets of spores are shown.

To confirm that BsCsp3 supplies $\mathrm{Cu}(\mathrm{I})$ to $B s \mathrm{CotA}$ in vivo, the $\Delta c s p 3$ strain was complemented by introducing an inducible copy of the csp3 gene at a different location (the amyE locus). The highest $B s C o t A$ activity is obtained for spores of this strain grown in the presence of isopropyl $\beta$ D-thiogalactopyranoside (IPTG, the inducer) and Cu (Figure 2c,d). Activity is almost three-fold greater than without their addition, similar to the increase caused by $\mathrm{Cu}$ in WT B. subtilis spores

158 (Figure 2a). Elevated activity is observed for spores from the complemented strain grown with $159 \mathrm{Cu}$, but not IPTG, present in the media (Figure 2c). To ensure this effect is due to leaky expression, a well-established feature of the promoter used [for example, see ref. 30], a control $\Delta c s p 3$ strain was constructed (see Material and Methods). In this case, the ability to oxidise

162 ABTS is hardly influenced by the presence of Cu and IPTG (Supplementary Figure 5).

163 Therefore, the increased BsCotA activity for the complemented $\Delta c s p 3$ strain is due to the IPTG164 inducible copy of the csp3 gene. 


\section{$\mathrm{Cu}(\mathrm{I})$ transfer from $\mathrm{BsCsp3}$ to BsCotA in vitro}

166 The above data support the hypothesis that $\mathrm{BsCsp3}$ can store $\mathrm{Cu}(\mathrm{I})$ in the cytosol under $\mathrm{Cu}$ -

167 replete conditions, which is used to metallate $B s C o t A$. To further test this idea, the transfer of

$168 \mathrm{Cu}(\mathrm{l})$ from BsCsp3 to inactive apo(Cu-free)-BsCotA has been studied in vitro. We have previously found $(12,13)$ that $\mathrm{Cu}(\mathrm{I})$ removal from $\mathrm{Csp3s}$ by a large excess of high-affinity $\mathrm{Cu}(\mathrm{I})$ ligands is slow ( $60 \%$ removal in $24 \mathrm{~h}$ for BsCsp3 using bathocuproine disulfonate, see

171 Supplementary Figure 6 and Table 2). The transfer of $\mathrm{Cu}(\mathrm{I})$ from BsCsp3 to BsCotA occurs

172 quickly when using a 10 -fold excess of $\mathrm{Cu}(\mathrm{I})$ in the storage protein over sites in the enzyme,

173 and $>50 \%$ maximum activity is achieved within $6 \mathrm{~h}$ (Figure $3 \mathrm{a}, \mathrm{b}$ and Figure $4 \mathrm{a}$ ). A control experiment was performed studying activation of as-isolated $\mathrm{BsCotA}$ with $\mathrm{Cu}(\mathrm{I})$ in the absence of BsCsp3, which is faster, but still takes $4 \mathrm{~h}$ to complete.
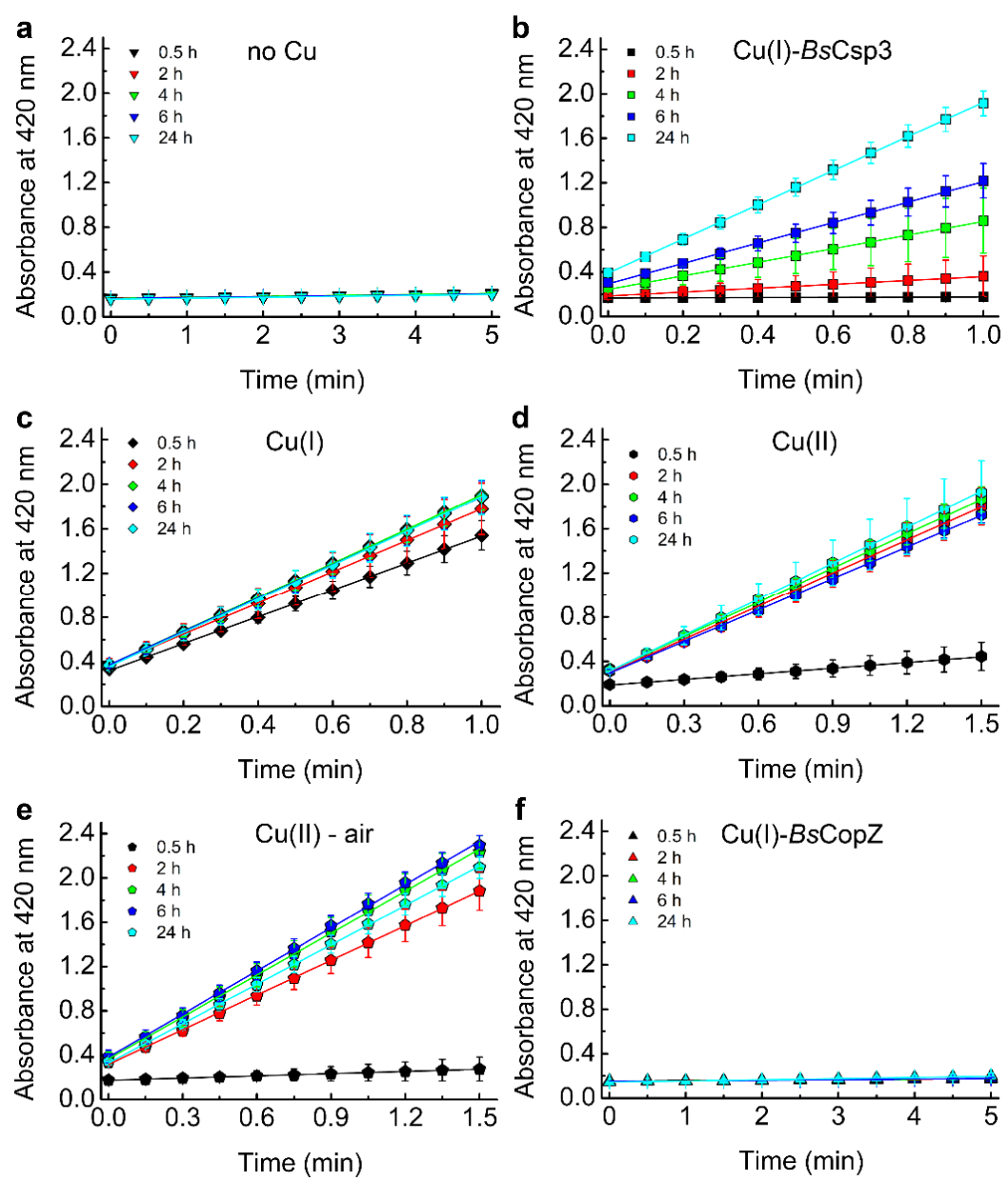

Time $(\min )$

Time $(\min )$

177 Figure 3. Kinetic analysis of the activity of $B s C o t A$ after incubation with $\mathrm{Cu}$ from difference sources. Plots of absorbance at $420 \mathrm{~nm}$ against time for the reaction with $2.4 \mathrm{mM}$ ABTS of mixtures of apo-BsCotA incubated with buffer (a), $\mathrm{Cu}(\mathrm{I})-\mathrm{BsCsp} 3(\mathrm{~b}), \mathrm{Cu}(\mathrm{I})(\mathrm{c}), \mathrm{Cu}(\mathrm{II})$ (d and e) and $\mathrm{Cu}(\mathrm{I})-\mathrm{BsCopZ}$ (f) for 0.5, 2, 4, 6 and $24 \mathrm{~h}$. Mixtures were incubated in $20 \mathrm{mM} \mathrm{HEPES} \mathrm{pH} 7.5$ plus $200 \mathrm{mM} \mathrm{NaCl}$ (the buffer used in a), and $B s C o t A$ activity was measured $100 \mathrm{mM}$ citrate-phosphate buffer $\mathrm{pH}$ 4.0. All data (averages from three independent experiments with error bars showing standard deviations) are from mixtures incubated under anaerobic conditions, apart form in e when $\mathrm{BsCotA}$ and $\mathrm{Cu}(\mathrm{II})$ were incubated in air. The resulting activity data at these and other incubation times are shown in Figure 4. 
A further control was carried out using $\mathrm{Cu}(\mathrm{II})$ and metalation of the enzyme is slower than for $\mathrm{Cu}(\mathrm{I})$ both under anaerobic and aerobic conditions (Figure 3c-e and Figure 4b). Another cytosolic $\mathrm{Cu}(\mathrm{I})$-binding protein with a well-established role (18) in Cu homeostasis (delivering $\mathrm{Cu}(\mathrm{I})$ to $\mathrm{BsCopA}$ ) and a similar $\mathrm{Cu}(\mathrm{I})$ affinity (31) to BsCsp3 (13) is BsCopZ (see Figure 1a). As this was another potential source of $\mathrm{Cu}(\mathrm{I})$ for $\mathrm{BsCotA}$ we tested to see if $\mathrm{BsCopZ}$ could transfer $\mathrm{Cu}(\mathrm{I})$ to $\mathrm{BsCotA}$ (Figure $3 \mathrm{f}$ and Figure $4 \mathrm{a}$ ). After the incubation of apo-BsCotA with $\mathrm{Cu}(\mathrm{I})$ BsCopZ for $48 \mathrm{~h}$ very little activity is observed, and $\mathrm{Cu}(\mathrm{l})$ transfer does not occur.
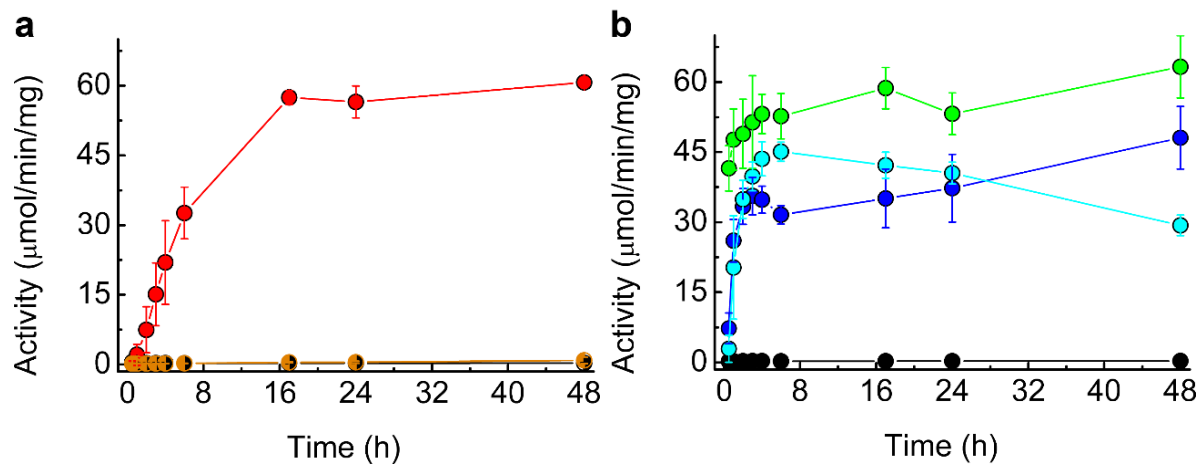

Figure 4. $\mathrm{Cu}(\mathrm{l})$ transfer from $\mathrm{BsCsp} 3$ to $\mathrm{BsCotA}$. (a) Plots of activity (average from three independent experiments with error bars showing standard deviations) against incubation time of as-isolated BsCotA incubated with $\mathrm{Cu}(\mathrm{I})-\mathrm{BsCsp} 3$ (red circles), $\mathrm{Cu}(\mathrm{I})-B s \mathrm{CopZ}$ (half-orange circles) and buffer alone (half-black circles) for up to $48 \mathrm{~h}$ under anaerobic conditions. The activity data for as-isolated BsCotA plus buffer alone (black circles) are also shown in (b), as well as the results from control experiments in which the enzyme was incubated with $\mathrm{Cu}(\mathrm{I})$ (green circles) and $\mathrm{Cu}(\mathrm{II})$ under anaerobic conditions (blue circles), and also with $\mathrm{Cu}(\mathrm{II})$ in air (cyan circles). The kinetic data at selected time points are shown in Figure 3.

\section{Discussion}

Herein we demonstrate that $\mathrm{BsCsp3}$ stores $\mathrm{Cu}(\mathrm{I})$ in the cytosol during sporulation for the $\mathrm{Cu}$ requiring enzyme BsCotA. This is not the only mechanism available to load BsCotA with $\mathrm{Cu}$ as some activity is still observed in $\Delta \operatorname{csp} 3 B$. subtilis. A possibility we considered was that the cytosolic Cu metallochaperone $\mathrm{BsCopZ}$, as well as transferring $\mathrm{Cu}(\mathrm{I})$ to $\mathrm{BsCopA}$, may also store cuprous ions in the cytosol, which could be transferred to BsCotA (the $\mathrm{Cu}(\mathrm{I})$ affinity of BsCopZ is similar to that of $B s C s p 3(13,31))$. This is supported by the suggestion that BsCopZ could play a role in $\mathrm{Cu}(\mathrm{I})$ sequestration and recycling in $B$. subtilis (18) as less $\mathrm{Cu}$ accumulates in the $\Delta c o p Z$ strain compared to WT. Furthermore, the activity of CotA from a different Bacillus strain is enhanced when co-expressed in the cytosol of $E$. coli with its native CopZ (32). However, the in vitro studies reported here show that $B s C o p Z$ cannot transfer $\mathrm{Cu}(\mathrm{I})$ to $\mathrm{BsCotA}$ (Figure $3 \mathrm{f}$ and Figure 4a). The source(s) of $\mathrm{Cu}(\mathrm{l})$ for activating $\mathrm{BsCotA}$ in the absence of $\mathrm{BsCsp3}$, and also at lower intracellular concentrations of the metal ion, remain(s) to be established. Regardless, the lack of $\mathrm{Cu}(\mathrm{I})$ transfer from $B s C o p Z$ highlights the specificity of the BsCsp3-BsCotA interaction. This is essential in a cell as it ensures protein-mediated $\mathrm{Cu}(\mathrm{I})$ transfer to the correct destination, as observed for other Cu-homeostasis proteins (1, 33-39). 
Considering the high $\mathrm{Cu}(\mathrm{I})$ affinity $(13)$ of $\mathrm{BsCsp} 3\left((1.5 \pm 0.4) \times 10^{17} \mathrm{M}^{-1}\right)$, transfer of cuprous ions to $B s C o t A$ has to occur via an associative mechanism (unassisted $\mathrm{Cu}(\mathrm{I})$ off-rates for $B s C s p 3$ can be estimated (14) to be $\sim 10^{-9} \mathrm{~s}^{-1}$ ). For the acquisition of such tightly bound $\mathrm{Cu}(\mathrm{I})$ to be possible, metalation must take place once the target enzyme has at least partially folded so the sites where $\mathrm{Cu}$ binds have formed. The T1 Cu site is closest to the surface of BsCotA (the His497 ligand is solvent exposed), and is $\sim 12.5-15.5 \AA$ from the $\mathrm{Cu}_{3}$ cluster (Figure 1c). Therefore, BsCsp3 association at more than one location may be required to metalate all of the sites in folded BsCotA. Published $\mathrm{Cu}(\mathrm{I})$ affinities of T1 Cu sites $(40,41)$ are $(2.1-4.0) \times 10^{17} \mathrm{M}^{-1}$, similar to the average $\mathrm{Cu}(\mathrm{I})$ affinity of $\mathrm{BsCsp} 3(13)$. Therefore, $\mathrm{Cu}(\mathrm{I})$ transfer from the storage protein to the enzyme should not be hindered thermodynamically $(37,40)$. To facilitate access to the more buried $\mathrm{Cu}_{3}$ cluster the protein may need to be partially unfolded. The $\mathrm{MCO} \mathrm{CueO}$ from E. coli undergoes a transition from an 'open' non-metallated folded form with accessible $\mathrm{Cu}$ sites, to a more 'closed' conformation after Cu has bound (42). A similar change may occur in BsCotA to facilitate $\mathrm{Cu}(\mathrm{I})$ loading by BsCsp3.
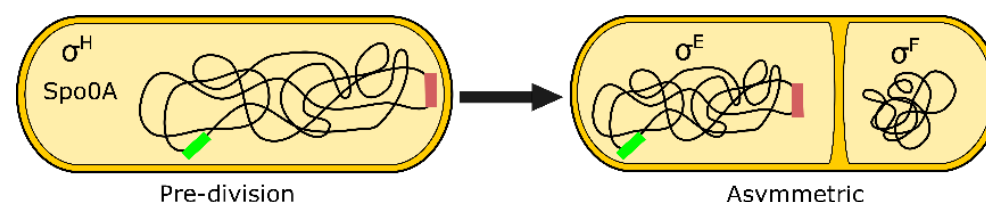

Pre-division

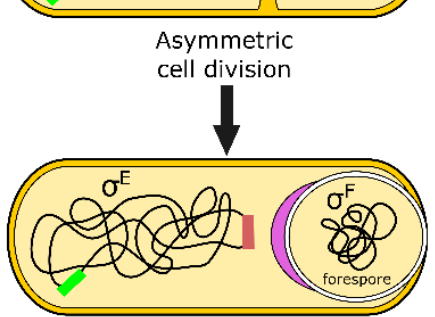

Pre-engulfment

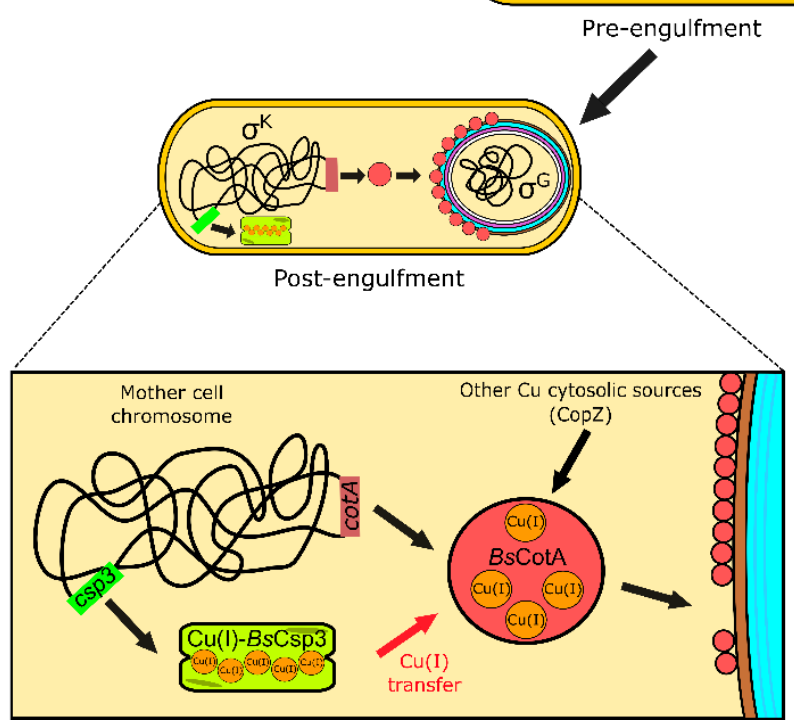

Figure 5. The proposed role of $B s C s p 3$ in $\mathrm{Cu}(\mathrm{I})$ acquisition by $B s C o t A$ during sporulation in $B$. subtilis. The transcription factor SpoOA, along with $\sigma^{\mathrm{H}}$, initiates sporulation. A septum asymmetrically divides the cell into the forespore and mother cell, with $\sigma^{\mathrm{E}}$ and $\sigma^{F}$, respectively, activated within these. The mother cell begins engulfment of the forespore and $\sigma^{\mathrm{E}}$ directs gene expression and initiation of spore coat (purple) formation. The expression of BsCsp3 and BsCotA now begins, promoted by $\sigma^{\mathrm{K}}$ (see Figure 1f) and coat 
assembly continues. We propose that $B s C s p 3$ acquires $\mathrm{Cu}(\mathrm{I})$ during this stage of sporulation, which is transferred to BsCotA prior to insertion of the Cu-enzyme into the spore coat.

The expression of both BsCsp3 and BsCotA are regulated by sigma factor K (SigK or $\sigma^{\mathrm{K}}$ ), which is produced after the forespore has been engulfed by the mother cell (Figure 5). Upregulation of the $\operatorname{csp} 3$ gene occurs prior to $\cot A$ (Figure 1f), thus allowing the storage protein to acquire $\mathrm{Cu}(\mathrm{I})$ before production of the enzyme requiring the metal. As $B s \operatorname{Cot} A$ is one of the last proteins to be added to the spore coat (28), $\mathrm{Cu}(\mathrm{I})$ transfer from $\mathrm{BsCsp3}$ could occur during the very late stages of sporulation. Where BsCsp3 acquires $\mathrm{Cu}(\mathrm{I})$ from is not known, but possible sources are Cu-enzymes that are not required by the spore, with the only currently known possibilities being COXs. The finding that $B s C s p 3$ provides $\mathrm{Cu}(\mathrm{I})$ to an enzyme requiring this metal ion suggests a similar role is performed by Csp3s in the cytosol of other bacteria. The novelty of this finding is further highlighted by there being only one currently known example of $\mathrm{Cu}$ acquisition by an enzyme from a partner protein in the cytosol. This is from the eukaryotic $\mathrm{Cu}$ metallochaperone CCS to the $\mathrm{Cu}, \mathrm{Zn}$-superoxide dismutase, which has been studied in considerable detail $(1,34,35,37-39,43,44)$.

Added importance to understanding correct metalation of $B s C o t A$ is provided by the observation that melanin formation interferes with the phagocytosis of pathogenic yeast, and is required to allow survival in macrophages (45). The related pigment produced by Cu-loaded BsCotA is important for spore survival $(25,28)$, and this may include within a host. Bacillus spores, and particularly those from $B$. cereus, cause food poisoning and are a common contaminant in a range of foods $(46,47)$. The development of more effective inactivation approaches requires a better understanding of enzymes that help protect spores such as CotA. This includes establishing how they acquire essential cofactors including $\mathrm{Cu}$ ions.

\section{Materials and Methods}

\section{Growth curves for WT and $\Delta \operatorname{csp} 3 B$. subtilis at increasing $\mathrm{Cu}$}

\section{concentrations}

WT and $\Delta \operatorname{csp} 3 B$. subtilis 168 strains were obtained from the Bacillus Genetic Stock Centre library. The disrupted csp3 gene ( $y$ hjQ) was amplified by PCR using genomic DNA from the $\Delta c s p 3$ strain with primers that hybridise $\sim 300$ bp upstream and downstream of this region (Supplementary Table 3). The resulting fragment was sequenced with primers designed to hybridise $\sim 20 \mathrm{bp}$ from the ends of the PCR product (Supplementary Table 3) and matches that of the erythromycin resistance gene. To test the influence of $\mathrm{Cu}$ on WT and $\Delta c s p 3$ strains, cultures were grown (agitation at $250 \mathrm{rpm}$ ) in LB media at $37^{\circ} \mathrm{C}$ overnight, diluted $(\sim 100$-fold) in $\mathrm{LB}$ and $\mathrm{LB}$ plus $\mathrm{Cu}\left(\mathrm{NO}_{3}\right)_{2}(0.5$ to $2.0 \mathrm{mM})$. The absorbance at $600 \mathrm{~nm}$ was measured at regular 
intervals for up to $12 \mathrm{~h}$, and also after $24 \mathrm{~h}$ growth. The Cu concentration in the stock solution used for these studies was regularly determined by atomic absorption spectrometry (AAS), as described previously (15).

\section{The construction of $B$. subtilis strains}

To re-insert the $\operatorname{csp} 3$ gene plus its ribosome binding site (RBS) into the $\Delta \operatorname{csp} 3$ strain, a region including an additional $28 \mathrm{bp}$ at the 5' end was amplified from $B$. subtilis 168 genomic DNA by PCR using primers; rbs_BsCsp3-F and rbs_BsCsp3-R (Supplementary Table 3). The product was cloned into pGEM-T (Promega) and the resulting rbs_csp3 fragment sub-cloned into pDR111, which possesses the IPTG-inducible $P_{\text {hyerspank }}$ promoter (48), using HindIII and Nhel to generate pDR111_rbs_csp3. To obtain a strain possessing an IPTG-inducible copy of the csp3 gene (complemented $\Delta c s p 3$ ), $\Delta c s p 3 B$. subtilis was transformed with pDR111_rbs_csp3.

Selection was achieved using spectinomycin $(50 \mu \mathrm{g} / \mathrm{mL})$ and successful integration into the chromosomal amyE ( $\alpha$-amylase) gene identified by growing on LB agar containing $1 \%$ starch and staining with iodine (49). A strain of $\Delta \operatorname{csp} 3 B$. subtilis in which the region of pDR111 lacking the csp3 gene was integrated into the genome (control $\Delta c s p 3$ ) was also generated. The size of the fragment incorporated was confirmed by PCR using the primers pDR111_int_F and pDR111_int_R (Supplementary Table 3).

\section{The production of $B$. subtilis spores}

WT, $\Delta \operatorname{csp} 3$, complemented $\Delta \operatorname{csp} 3$ and control $\Delta \operatorname{csp} 3$ strains were grown overnight (agitation at $250 \mathrm{rpm}$ ) in $20 \mathrm{~mL}$ Difco sporulation media (DSM). Cultures were diluted 50 -fold into $200 \mathrm{~mL}$ DSM in a single $1 \mathrm{~L}$ Erlenmeyer flask and grown until the absorbance at $580 \mathrm{~nm}$ reached $\sim 0.5$. This was split into four $50 \mathrm{~mL}$ cultures, each in a $250 \mathrm{~mL}$ Erlenmeyer flask, and $50 \mu \mathrm{M} \mathrm{Cu}\left(\mathrm{NO}_{3}\right)_{2}$ and $1 \mathrm{mM}$ IPTG added when required. The cultures were grown (agitation at $250 \mathrm{rpm}$ ) at $37{ }^{\circ} \mathrm{C}$ for $48 \mathrm{~h}$ and absorbance values at $580 \mathrm{~nm}$ measured at regular intervals. To purify spores (50) cultures were centrifuged $\left(4^{\circ} \mathrm{C}\right)$ for $10 \mathrm{~min}$ at $5,000 \mathrm{~g}$, pellets re-suspended in $50 \mathrm{mM}$ Tris $\mathrm{pH}$ 7.2 plus $50 \mu \mathrm{g} / \mathrm{mL}$ lysozyme and incubated at $37^{\circ} \mathrm{C}$ for $1 \mathrm{~h}$. After incubation and further centrifugation $\left(4^{\circ} \mathrm{C}\right)$ for $10 \mathrm{~min}$ at $5,000 \mathrm{~g}$, pellets were washed once in sterile MilliQ water and centrifuged. The pellets were re-suspended in $0.05 \%$ SDS by vortexing, centrifuged $\left(4^{\circ} \mathrm{C}\right)$ for 10 min at 5,000 $\mathrm{g}$ and subsequently washed three times with sterile MilliQ water. The purified spore stocks were verified by PCR (for example, Supplementary Figure 7) using primers listed in Supplementary Table 3 and stored at $4{ }^{\circ} \mathrm{C}$.

\section{BsCotA activity of purified spores}

For kinetic measurements of BsCotA activity, purified spores from the WT, $\Delta \operatorname{csp} 3$, complemented $\Delta c s p 3$, and control $\Delta c s p 3$ strains were diluted with MilliQ water to give an 
absorbance at $580 \mathrm{~nm}$ of $\sim 1.2$ (measured accurately), and heated at $65^{\circ} \mathrm{C}$ for $1 \mathrm{~h}$ prior to use. To determine the colony forming units per $\mathrm{mL}(\mathrm{CFUs} / \mathrm{mL})$ for this suspension a $5 \times 10^{5}$-fold dilution in LB was plated $(100 \mu \mathrm{L})$ onto LB agar. The plates were incubated at $37^{\circ} \mathrm{C}$ overnight and colonies counted. An aliquot of the heat-treated spore suspension (100 $\mu \mathrm{L})$ was added to $900 \mu \mathrm{L}$ of $100 \mathrm{mM}$ citrate-phosphate buffer $\mathrm{pH} 4.0$ plus $0.1-2.4 \mathrm{mM}$ ABTS, and the absorbance at $420 \mathrm{~nm}\left(\varepsilon=3.5 \times 10^{4} \mathrm{M}^{-1} \mathrm{~cm}^{-1}\right)$ measured for $5 \mathrm{~min}$ at $37^{\circ} \mathrm{C}$ (Supplementary Figure 3). A control using $100 \mu \mathrm{L}$ of buffer was also measured and showed no change in absorbance at 420 $\mathrm{nm}$. The initial velocity ( $V_{0}$; typically reported in units of $\left.\mu \mathrm{M} / \mathrm{min} / \mathrm{CFUs} / \mathrm{mL}\right)$ was calculated, and plots of $V_{0}$ against ABTS concentration (Figure 2 and Supplementary Figure 5 ) were fit to the Michaelis-Menten equation to determine $V_{\max }$ (the maximum rate) and $K_{\mathrm{M}}$ (the Michaelis constant). Comparing $V_{\max }$ values calculated based on the absorbance at $580 \mathrm{~nm}$ of the heattreated spore suspension, rather than using CFUs/mL, has no significant influence on the outcome of the study, but generally produces data with larger errors. The reactivity of heattreated purified spores from WT and $\Delta \operatorname{csp} 3 B$. subtilis with $2.4 \mathrm{mM} \mathrm{ABTS}$ was compared to that of the same spore suspension incubated with $250 \mu \mathrm{M} \mathrm{Cu}\left(\mathrm{NO}_{3}\right)_{2}$ for $30 \mathrm{~min}$ at room temperature.

\section{Cloning and purification of BsCotA}

The cotA gene was amplified from $B$. subtilis genomic DNA using primers CotA_1F and CotA_1R listed in Supplementary Table 3, and cloned into pGEM-T. After removing the Ndel site in the gene by QuickChange site-directed mutagenesis (with primers CotA_2F and CotA_2R, Supplementary Table 3), the product was excised with $\mathrm{Ndel}$ and $\mathrm{BamHI}$ and re-cloned into pET11a. BsCotA was overexpressed in BL21 E. coli (100 $\mu \mathrm{M}$ IPTG) grown at $20^{\circ} \mathrm{C}$ for $24 \mathrm{~h}$. The protein was purified using a modified version of a published procedure (26). Cells from 0.5 to 1.0 $L$ of culture were resuspended in $20 \mathrm{mM}$ Tris $\mathrm{pH} 8.5$, sonicated and centrifuged at $40,000 \mathrm{~g}$ for $30 \mathrm{~min}$. The supernatant was diluted five-fold in $20 \mathrm{mM}$ Tris $\mathrm{pH} 8.5$ and loaded onto a HiTrap Q $\mathrm{HP}$ column (1 mL) equilibrated in the same buffer. Proteins were eluted with a linear $\mathrm{NaCl}$ gradient $(0-500 \mathrm{mM}$, total volume $50 \mathrm{~mL})$ and fractions analysed using $18 \%$ SDS-PAGE. BsCotA-containing fractions were diluted with $20 \mathrm{mM}$ Tris $\mathrm{pH} 7.6$ and loaded onto a HiTrap SP $\mathrm{HP}$ column $(5 \mathrm{~mL})$ and eluted with a linear $\mathrm{NaCl}$ gradient $(0-500 \mathrm{mM}$, total volume, $200 \mathrm{~mL})$. The BsCotA-containing fractions were heated at $70^{\circ} \mathrm{C}$ for $30 \mathrm{~min}$ (BsCotA is a highly thermostable enzyme (26)), centrifuged at $40,000 \mathrm{~g}$ for $30 \mathrm{~min}$, and the supernatant exchanged into $20 \mathrm{mM}$ HEPES pH 7.5 plus $200 \mathrm{mM} \mathrm{NaCl}$ for further purification on a Superdex 75 10/300 GL gelfiltration column. Purified BsCotA had very little $\mathrm{Cu}$ or $\mathrm{Zn}$ (II) (the latter, a metal ion that commonly binds to Cu proteins when overexpressed in the cytosol of $E$. coli) associated with it when analysed by AAS $(12,13)$, and showed almost no ABTS oxidation activity. Samples ( 3-12 $\mu \mathrm{M}$, quantified using an $\varepsilon$ value of $84,739 \mathrm{M}^{-1} \mathrm{~cm}^{-1}$ at $\left.280 \mathrm{~nm}(51)\right)$ were incubated with $250 \mu \mathrm{M}$ $\mathrm{Cu}\left(\mathrm{NO}_{3}\right)_{2}$, thoroughly exchanged and subsequently washed with a low concentration $(\sim 10 \mu \mathrm{M})$ of 
ethylenediaminetetraacetic acid (EDTA). This gave rise to Cu-loaded BsCotA with a $k_{\text {cat }}$ value of 20-40 s-1 for the oxidation of ABTS, compared to a literature value of $22 \mathrm{~s}^{-1}$ for Cu-enzyme produced using a similar procedure (51).

\section{Purification of BsCopZ and sample preparation}

BsCopZ is purified with a small amount of $\mathrm{Zn}$ (II) bound, as described previously (13). Samples were therefore incubated with $>10$ equivalents of EDTA for $1 \mathrm{~h}$ and exchanged with $20 \mathrm{mM}$ HEPES pH 7.5 plus $200 \mathrm{mM} \mathrm{NaCl}$. The resulting protein had no $\mathrm{Zn}$ (II) associated with it and was reduced with dithiothreitol under anaerobic conditions and desalted as described previously (12, 13).

\section{Analysing $\mathrm{Cu}(\mathrm{l})$ transfer from recombinant $B s C s p 3$ and $B s C o p Z$ to $B s C o t A$}

BsCsp3 binding 18 equivalents of $\mathrm{Cu}(\mathrm{I})$ was prepared by adding the appropriate amount of a buffered solution of $\mathrm{Cu}(\mathrm{I})$ in an anaerobic chamber (Belle Technology, $\mathrm{O}_{2}<<2 \mathrm{ppm}$ ) to apoprotein in $20 \mathrm{mM}$ HEPES pH 7.5 plus $200 \mathrm{mM} \mathrm{NaCl}$, quantified using the 5,5'-dithiobis(2nitrobenzoic acid) (DTNB) assay $(12,13)$. Fully-reduced BsCopZ was also quantified using the DTNB assay and loaded with $\sim 0.8$ equivalents of $\mathrm{Cu}(\mathrm{I})$ under anaerobic conditions. $\mathrm{Cu}(\mathrm{I})-$ BsCsp3 ( 3 $\mu \mathrm{M}$ binding $\sim 53-54 \mu \mathrm{M} \mathrm{Cu}(\mathrm{I}))$ was mixed with $\sim 1.3 \mu \mathrm{M}$ of as-isolated BsCotA, requiring $\sim 5.6 \mu \mathrm{M} \mathrm{Cu}(\mathrm{I})$ to occupy all Cu sites. Cu(I)-BsCopZ ( 50-53 $\mu \mathrm{M}$ binding $\sim 40-42 \mu \mathrm{M}$ $\mathrm{Cu}(\mathrm{I}))$ was separately added to $\sim 1 \mu \mathrm{M}$ of as-isolated $B s \mathrm{Cot} A$, requiring $\sim 4 \mu \mathrm{M} \mathrm{Cu}(\mathrm{I})$ to fill all $\mathrm{Cu}$ sites. Mixtures were incubated at room temperature in the anaerobic chamber for up to $48 \mathrm{~h}$. A similar concentration of $B s C o t A$ was also incubated anaerobically with $\mathrm{Cu}(\mathrm{I})$, prepared as described above, a $\mathrm{Cu}\left(\mathrm{NO}_{3}\right)_{2}$ solution (final concentrations of $\sim 56-58 \mu \mathrm{M}$ ), buffer $(20 \mathrm{mM}$ HEPES pH 7.5 plus $200 \mathrm{mM} \mathrm{NaCl}$ ) alone, and also with $\mathrm{Cu}\left(\mathrm{NO}_{3}\right)_{2}$ in air. To measure activity, 10 $\mu \mathrm{L}$ of each mixture was added to $990 \mu \mathrm{L}$ of aerated $100 \mathrm{mM}$ citrate-phosphate buffer $\mathrm{pH} 4.0$ plus $2.4 \mathrm{mM} \mathrm{ABTS}$, and the absorbance at $420 \mathrm{~nm}$ measured for up to $5 \mathrm{~min}$ at $37^{\circ} \mathrm{C}$ (Figure 3 ). The removal of $\mathrm{Cu}(\mathrm{I})$ by $\mathrm{BCS}(\sim 2.5 \mathrm{mM})$ was analysed for $\mathrm{Cu}(\mathrm{I})-B s \mathrm{Csp} 3(\sim 0.8-1.2 \mu \mathrm{M}$ plus $\sim 18$ equivalents of $\mathrm{Cu}(\mathrm{I})$ ) samples used for the transfer experiments, both in the absence (folded BsCsp3) and presence (unfolding conditions) of guanidine- $\mathrm{HCl}(6.64 \mathrm{M})(12,13)$. The absorbance increase at $483 \mathrm{~nm}$ due to formation of $\left[\mathrm{Cu}(\mathrm{BCS})_{2}\right]^{3-}\left(\varepsilon=12,500 \mathrm{M}^{-1} \mathrm{~cm}^{-1}\right)(31)$ was measured over time at $22^{\circ} \mathrm{C}$ in $20 \mathrm{mM}$ HEPES pH 7.5 plus $200 \mathrm{mM} \mathrm{NaCl}$ (Supplementary Figure 6).

\section{Acknowledgments}

We thank BBSRC for funding (grant BB/K008439/1 to C.D.). We are grateful to Newcastle University for an Overseas Research Scholarship (ORS) award to J.L.. We also thank Prof. 
Heath Murray for help with generating B. subtilis mutant strains, Dr. Mark Harrison for cloning the cotA gene and Dr. Gianpiero Landolfi for purifying BsCopZ.

\section{Author contributions}

C.D. and J.L conceived the project and designed the experiments. J.L. performed the experiments and analysed data with help from C.D. C.D. wrote the manuscript with help from J.L.

\section{Competing interests}

The authors declare no competing interests.

\section{Additional information}

Supplementary information is available for this paper.

\section{References}

1. Rae, T. D., Schmidt, P. J., Pufahl, R. A., Culotta, V. C. \& O'Halloran, T. V. Undetectable intracellular free copper: The requirement for a copper chaperone for superoxide dismutase. Science 284, 805-808 (1999) doi: 10.1126/science.284.5415.805.

2. Changela, A., Chen, K., Xue, Y., Holschen, J., O’Halloran, T. V. \& Mondragón, A. Molecular basis of metal-ion selectivity and zeptomolar sensitivity by CueR. Science 301, 1383-1387 (2003) doi: 10.1126/science.1085950.

3. Festa, R. A. \& Thiele, D. J. Copper: an essential metal in biology. Curr. Biol. 21, R877R883 (2011) doi: 10.1016/j.cub.2011.09.040.

4. Marckmann, D., Trasnea, P. I., Schimpf, J., Winterstein, C., Andrei, A., Schmoller, S., Blaby-Haas, C. E., Friedrich, T., Daldal, F. \& Koch, H. G. The $c b b_{3}$-type cytochrome oxidase assembly factor $\mathrm{C} c 0 \mathrm{G}$ is a widely distributed cupric reductase. Proc. Natl. Acad. Sci. USA 116, 21166-21175 (2019) doi: 10.1073/pnas.1913803116.

5. Hassett, R. \& Kosman, D. J. Evidence for $\mathrm{Cu}(\mathrm{II})$ reduction as a component of copper uptake by Saccharomyces cerevisiae. J. Biol. Chem. 270, 128-134 (1995) doi: 10.1074/jbc.270.1.128.

6. Rensing, C., Fan, B., Sharma, R., Mitra, B. \& Rosen, B. P. CopA: An Escherichia coli Cu(I)translocating P-type ATPase. Proc. Natl. Acad. Sci. USA 97, 652-656 (2000) doi: 10.1073/pnas.97.2.652.

7. Solioz, M., Abicht, H. K., Mermod, M. \& Mancini, S. Response of Gram-positive bacteria to copper stress. J. Biol. Inorg. Chem. 15, 3-14 (2010) doi: 10.1007/s00775-009-0588-3.

8. Rensing, C. \& McDevitt S. F. The copper metallome in prokaryotic cells. Met. Ions Life Sci. 12, 417-450 (2013) doi: 10.1007/978-94-007-5561-1_12. 
9. Meydan, S., Klepacki, D., Karthikeyan, S., Margus, T., Thomas, P., Jones, J. E., Khan, Y., Briggs, J., Dinman, J. D., Vázquez-Laslop, N. \& Mankin, A. S. Programmed ribosomal frameshifting generates a copper transporter and a copper chaperone from the same gene. Mol. Cell. 65, 207-219 (2017) doi: 10.1016/j.molcel.2016.12.008.

10. Macomber, L. \& Imlay, J. A. The iron-sulfur clusters of dehydratases are primary intracellular targets of copper toxicity. Proc. Natl. Acad. Sci. USA 106, 8344-8349 (2009) doi: 10.1073/pnas.0812808106.

11. Ridge, P. G., Zhang, Y. \& Gladyshev, V. N. Comparative genomic analyses of copper transporters and cuproproteomes reveal evolutionary dynamics of copper utilization and its link to oxygen. PLoS One 3, e1378 (2008) doi: 10.1371/journal.pone.0001378.

12. Vita, N., Platsaki, S., Baslé, A., Allen, S. J., Paterson, N. G., Crombie, A. T., Murrell, J. C., Waldron, K. J. \& Dennison, C. A four-helix bundle stores copper for methane oxidation. Nature 525, 140-143 (2015) doi: 10.1038/nature14854.

13. Vita, N., Landolfi, G., Baslé, A., Platsaki, S., Lee, J., Waldron, K. J. \& Dennison, C. Bacterial cytosolic proteins with a high capacity for $\mathrm{Cu}(\mathrm{I})$ that protects against copper toxicity. Sci. Rep. 6, 39065 (2016) doi: 10.1038/srep39065.

14. Dennison, C., David, S. \& Lee, J. Bacterial copper storage proteins. J. Biol. Chem. 293, 4616-4627 (2018) doi: 10.1074/jbc.TM117.000180.

15. Lee, J. \& Dennison, C. Cytosolic copper binding by a bacterial storage protein and interplay with copper efflux. Int. J. Mol. Sci. 20, 4144 (2019) doi: 10.3390/ijms20174144.

16. Gu, W. \& Semrau, J. D. Copper and cerium-regulated gene expression in Methylosinus trichosporium OB3b. Appl. Microbiol. Biotechnol. 101, 8499-8516 (2017) doi: 10.1007/s00253-017-8572-2.

17. DiSpirito, A. A., Semrau, J. D., Murrell, J. C., Gallagher, W. H., Dennison C. \& Vuilleumier, $S$. Methanobactin and the link between copper and bacterial methane oxidation. Microbiol. Mol. Biol. Rev. 80, 387-409 (2016) doi: 10.1128/MMBR.00058-15.

18. Radford, D. S., Kihlken, M. A., Borrelly, G. P. M., Harwood, C. R., Le Brun, N. E. \& Cavet, J. S. CopZ from Bacillus subtilis interacts in vivo with a copper exporting CPx-type ATPase CopA. FEMS Microbiol. Lett. 220, 105-12 (2003) doi: 10.1016/S0378-1097(03)00095-8.

19. Smaldone, G. T. \& Helmann, J. D. CsoR regulates the copper efflux operon copZA in Bacillus subtilis. Microbiology 153, 4123-4128 (2007) doi: 10.1099/mic.0.2007/011742-0.

20. Chillappagari, S., Miethke, M., Trip, H., Kuipers, O. P. \& Marahiel, M. M. Copper acquisition is mediated by $\mathrm{YcnJ}$ and regulated by $\mathrm{YcnK}$ and CsoR in Bacillus subtilis. J. Bacteriol. 191, 2362-2370 (2009) doi: 10.1128/JB.01616-08.

21. Ma, Z., Cowart, D. M., Scott, R. A. \& Giedroc, D. P. Molecular insights into the metal selectivity of the copper(I)-sensing repressor CsoR from Bacillus subtilis. Biochemistry $\mathbf{4 8}$, 3325-3334 (2009) doi: 10.1021/bi900115w. 
22. Hirooka, K., Edahiro, T., Kimura, K. \& Fujita, Y. Direct and indirect regulation of the $y c n K J I$ operon involved in copper uptake through two transcriptional respresors, YcnK and CsoR, in Bacillus subtilis. J. Bacteriol. 194, 5675-5687 (2012) doi: 10.1128/JB.00919-12.

23. Damle, M. S., Singh, A. N., Peters, S. C., Szalai, V. A. \& Fisher, O. S. The Ycnl protein from Bacillus subtilis contains a copper-binding domain. J. Biol. Chem. 297, 101078 (2021) doi: 10.1016/j.jbc.2021.101078.

24. Lauraeus, M., Haltia, T., Saraste, M. \& Wikström, M. Bacillus subtilis expresses two kinds of haem-A-containing terminal oxidases. Eur. J. Biochem. 197, 699-705 (1991) doi: 10.1111/j.1432-1033.1991.tb15961.x.

25. Hullo, M. F., Moszer, I., Danchin, A. \& Martin-Verstraete, I. CotA of Bacillus subtilis is a copper-dependent laccase. J. Bacteriol. 183, 5426-5430 (2001) doi: 10.1128/JB.183.18.5426-5430.2001.

26. Martins, L. O., Soares, C. M., Pereira, M. M., Teixeira, M., Costa, T., Jones, G. H., Henriques, A. O. Molecular and biochemical characterisation of a highly stable bacterial laccase that occurs as a structural component of the Bacillus subtilis endospore coat. J. Biol. Chem. 277, 18849-18859 (2002) doi: 10.1074/jbc.M200827200.

27. Enguita, F. J., Martins, L. O., Henriques, A. O. \& Carrondo, M. A. Crystal structure of a bacterial endospore coat component. J. Biol. Chem. 278, 19416-19425 (2003) doi: 10.1074/jbc.M301251200.

28. McKenney, P. T., Driks, A. \& Eichenberger, P. The Bacillus subtilis endospore: assembly and functions of the multilayered coat. Nat. Rev. Microbiol. 11, 33-44 (2013) doi: 10.1038/nrmicro2921.

29. Nicolas, P. et al. Condition-dependent transcriptome reveals high-level regulatory architecture in Bacillus subtilis. Science 335, 1103-1106 (2012) doi: 10.1126/science.1206848.

30. Vavrová, L., Muchová, K. \& Barák, I. Comparison of different Bacillus subtilis expression systems. Res. Microbiol. 161, 791-797 (2010) doi: 10.1016/j.resmic.2010.09.004.

31. Badarau, A. \& Dennison, C. Copper trafficking mechanism of CXXC-containing domains: Insight from the $\mathrm{pH}$ dependence of their $\mathrm{Cu}(\mathrm{I})$ affinities. J. Am. Chem. Soc. 133, 2983-2988 (2011) doi: 10.1021/ja1091547.

32. Gunne, M., Al-Sultani, D. \& Urlacher, V. Enhancement of copper content and specific activity of CotA laccase from Bacillus licheniforms by coexpression with CopZ copper chaperone in E. coli. J. Biotechnol. 168, 252-255 (2013) doi: 10.1016/j.jbiotec.2013.06.011.

33. Pufahl, R. A., Singer, C. P., Peariso, K. L., Lin, S. J., Schmidt, P. J., Fahrni, C. J., Culotta, V. C., Penner-Hahn, J. E. \& O'Halloran T. V. Metal ion chaperone function of the soluble $\mathrm{Cu}(\mathrm{I})$ receptor Atx1. Science 278, 853-856 (1997) doi: 10.1126/science.278.5339.853.

34. Schmidt, P. J., Rae, T. D., Pufahl, R. A., Hamma, T., Strain, J., O'Halloran, T. V. \& Culotta, V. C. Multiple protein domains contribute to the action of the copper chaperone for 
superoxide dismutase. J. Biol. Chem. 274, 23719-23725 (1999) doi: 10.1074/jbc.274.34.23719.

35. Lamb, A. L., Torres, A. S., O'Halloran, T. V. \& Rosenzweig, A. C. Heterodimeric structure of superoxide dismutase in complex with its metallochaperone. Nat. Struct. Biol. 8, 751-755 (2001) doi: 10.1038/nsb0901-751.

36. Banci, L., Bertini, I., Cantini, F., Felli, I. C., Gonnelli, L., Hadjiliadis, N., Pierattelli, R., interaction. Nat. Chem. Biol. 2, 367-368 (2006) doi: 10.1038/nchembio797.

37. Banci, L., Bertini, I., Ciofi-Baffoni, S., Kozyreva, T., Zovo, K. \& Palumaa, P. Affinity gradients drive copper to cellular destinations. Nature 465, 645-648 (2010) doi: 10.1038/nature09018.

38. Banci, L., Bertini, I., Cantini, F., Kozyreva, T., Massagni, C., Palumaa, P., Rubino, J. T. \& Zovo, K. Human superoxide dismutase 1 (hSOD1) maturation through interaction with human copper chaperone for SOD1 (hCCS). Proc. Natl. Acad. Sci. USA 109, 13555-13560 (2011) doi: 10.1073/pnas.1207493109.

39. Sala, F. A., Wright, G. S. A., Antonyuk, S. V., Garratt, R. C. \& Hasnain, S. S. Molecular recognition and maturation of SOD1 by its evolutionary destabilised cognate chaperone hCCS. PLoS Biol. 17, e3000141 (2019) doi: 10.1371/journal.pbio.3000141.

40. Badarau, A. \& Dennison, C. Thermodynamics of copper and zinc distribution in the cyanobacterium Synechocystis PCC 6803. Proc. Natl. Acad. Sci. USA 108, 13007-13012 (2011) doi: 10.1073/pnas.1101448108.

41. North, M. L. \& Wilcox, D. E. Shift from entropic $\mathrm{Cu}^{2+}$ binding to enthaplic $\mathrm{Cu}^{1+}$ binding determines the reduction thermodynamics of blue copper proteins. J. Am. Chem. Soc. 141, 14329-14339 (2019) doi: 10.1021/jacs.9b06836.

42. Strolle, P., Hou, B. \& Brüser, T. The Tat substrate CueO is transported in an incomplete folding state. J. Biol. Chem. 291, 13520-13528 (2016) doi: 10.1074/jbc.M116.729103.

43. Culotta, V. C., Klomp, L. W., Strain, J., Casareno, R. L., Krems, B. \& Gitlin, J. D. The copper chaperone for superoxide dismutase. J. Biol. Chem. 272, 23469-23472 (1997) doi: 10.1074/jbc.272.38.23469.

44. Wong, P. C., Waggoner, D., Subramaniam, J. R., Tessarollo, L., Bartnikas, T. B., Culotta, V. C., Price, D. L., Rothstein, J. \& Gitlin J. D. Copper chaperone for superoxide dismutase is essential to active mammalian Cu/Zn superoxide dismutase. Proc. Natl. Acad. Sci. USA 97, 2886-2891 (2000) doi: 10.1073/pnas.040461197.

45. Eisenman, H. C. \& Casadevall, A. Synthesis and assembly of fungal melanin. Appl. Microbiol. Biotechnol. 93, 931-940 (2012) doi: 10.1007/s00253-011-3777-2.

46. Soni, A., Oey, I., Silcock, P. \& Bremer, P. Bacillus spores in the food industry: a review on resistance and response to novel inactivation technologies. Comp. Rev. Food Sci. Food Saf. 15, 1139-1148 (2016) doi: 10.1111/1541-4337.12231. 
47. Jessberger, N., Dietrich, R., Granum, P. E. \& Märtlbauer, E. The Bacillus cereus food infection as multifactorial process. Toxins, 12, 701 (2020) doi: 10.3390/toxins12110701.

48. Quisel, J. D., Burkholder, W. F. \& Grossman, A. D. In vivo effects of sporulation kinases on mutant Spo0A proteins in Bacillus subtilis. J. Bacteriol. 183, 6573-6578 (2001) doi: 10.1128/JB.183.22.6573-6578.2001.

49. Engman, J., Rogstam, A., Frees, D., Ingmer, H. \& von Wachenfeldt, C. The YjbH adaptor protein enhances proteolysis of the transcriptional regulator Spx in Staphylococcus aureus. J. Bacteriol. 194, 1186-1194 (2012) doi: 10.1128/JB.06414-11.

50. Tavares, M. B., Souza, R. D., Luiz, W. B., Cavalcante, R. C. M., Casaroli, C., Martins, E. G., Ferreira, R. C. C. \& Ferreira, L. C. S. Bacillus subtilis endospores at high purity and recovery yields: optimization of growth conditions and purification method. Curr. Microbiol. 66, 279-285 (2013) doi: 10.1007/s00284-012-0269-2.

51. Durão, P., Chen, Z., Fernandes, A. T., Hilderbrandt, P., Murgida, D. H. Todorovic, S., Pereira, M. M., Melo, E. P. \& Martins, L. O. Copper incorporation into recombinant CotA laccase from Bacillus subtilis: characterisation of fully copper loaded enzymes. J. Biol. Inorg. Chem. 13, 183-193 (2008) doi: 10.1007/s00775-007-0312-0. 
553 CONTENTS:

554 Supplementary Figure 1. The influence of Cu on the growth of WT and $\Delta \operatorname{csp} 3$ B. subtilis.

555 Supplementary Figure 2. The influence of $\mathrm{Cu}$ levels in media on $\mathrm{Cu}$ accumulation by WT and $556 \Delta \operatorname{csp} 3$ B. subtilis.

557 Supplementary Figure 3 The influence of deleting the csp3 gene and Cu levels on BsCotA 558 activity in $B$. subtilis strains.

559 Supplementary Figure 4. Testing spores for enhanced BsCotA activity in the presence of $\mathrm{Cu}$.

560 Supplementary Figure 5. The influence of Cu levels and IPTG on BsCotA activity in the control

$561 \Delta \operatorname{csp3} B$. subtilis strain.

562 Supplementary Figure 6. The removal of $\mathrm{Cu}(\mathrm{I})$ from BsCsp3 by the high-affinity ligand BCS.

563 Supplementary Figure 7. PCR analysis of purified spore stocks from the $B$. subtilis strains used 564 in this study.

565 Supplementary Table 1. The influence of Cu concentration on the BsCotA activity of purified 566 spores from WT and $\Delta c s p 3 B$. subtilis.

567 Supplementary Table 2. The removal of $\mathrm{Cu}(\mathrm{I})$ from BsCsp3 by BCS over time.

568 Supplementary Table 3. Primers used in this study. 

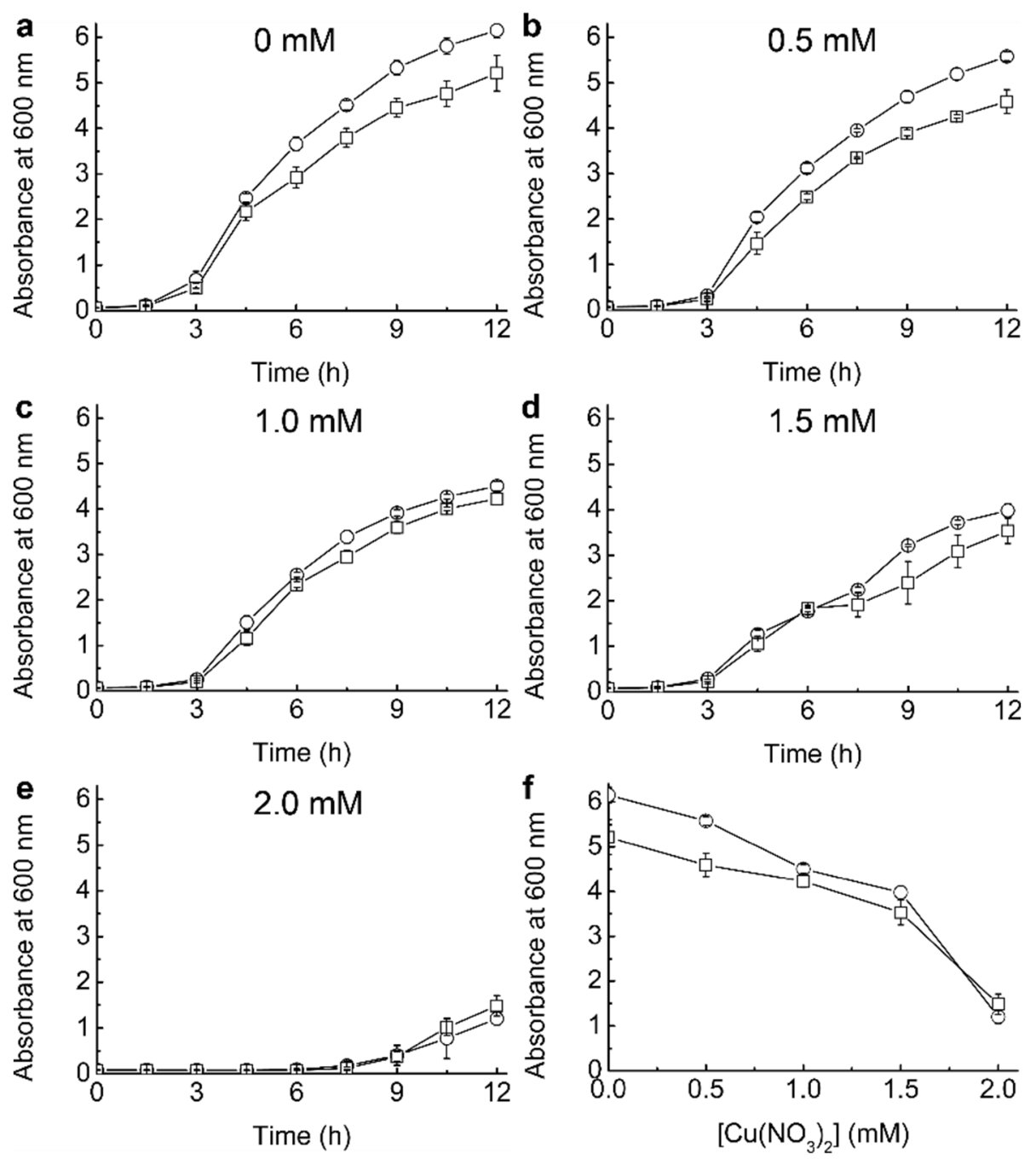

570 Supplementary Figure 1. The influence of $\mathrm{Cu}$ on the growth of WT and $\Delta \operatorname{csp} 3 B$. subtilis.

571 Growth $\left(37^{\circ} \mathrm{C}\right)$ of WT (circles) and $\Delta \operatorname{csp} 3$ (squares) B. subtilis in LB media plus 0 (a), 0.5 (b),

5721.0 (c), 1.5 (d), and 2.0 (e) $\mathrm{mM}$ added $\mathrm{Cu}\left(\mathrm{NO}_{3}\right)_{2}$. The data obtained at $12 \mathrm{~h}$ is compared in (f),

573 and in all cases averages and standard deviations from three independent growth experiments

574 are shown. These results are similar to those we reported previously (13), albeit the influence on

575 growth starts to be observed at a $\mathrm{Cu}$ (II) concentration in the media that is $\sim 0.5 \mathrm{mM}$ lower in this

576 work (we have quantified Cu levels in the stock solutions used herein by AAS, but did not

577 previously (13)). The absorbance of these cultures were also measured at $24 \mathrm{~h}$, and at up to 1.0

$578 \mathrm{mM}$ added $\mathrm{Cu}\left(\mathrm{NO}_{3}\right)_{2}$ a significant decrease was observed compared to the value at $12 \mathrm{~h}$ for both

579 strains (consistent with previous data (13)). At higher added $\mathrm{Cu}\left(\mathrm{NO}_{3}\right)_{2}$ concentrations, the

580 growth data showed no consistent pattern beyond $12 \mathrm{~h}$. This differs to the enhanced cell death

581 that was seen previously for $\Delta \operatorname{csp} 3 B$. subtilis after $12 \mathrm{~h}$ growth at reported media $\mathrm{Cu}$

582 concentrations of $1.5-2.0 \mathrm{mM}(13)$. 


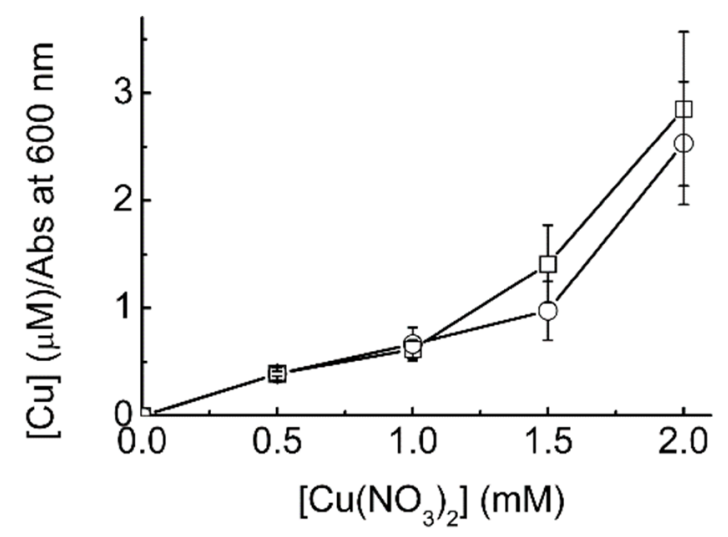

Supplementary Figure 2. The influence of Cu levels in media on Cu accumulation by WT and $\Delta \operatorname{csp3} B$. subtilis. The intracellular Cu concentrations for WT (circles) and $\Delta \operatorname{csp} 3$ (squares) $B$. subtilis grown for $12 \mathrm{~h}$ in LB media plus increasing amounts of added $\mathrm{Cu}\left(\mathrm{NO}_{3}\right)_{2}$. The data shown (average values and standard deviations) were measured for only two of the independent growth experiments, but the trend is clear.
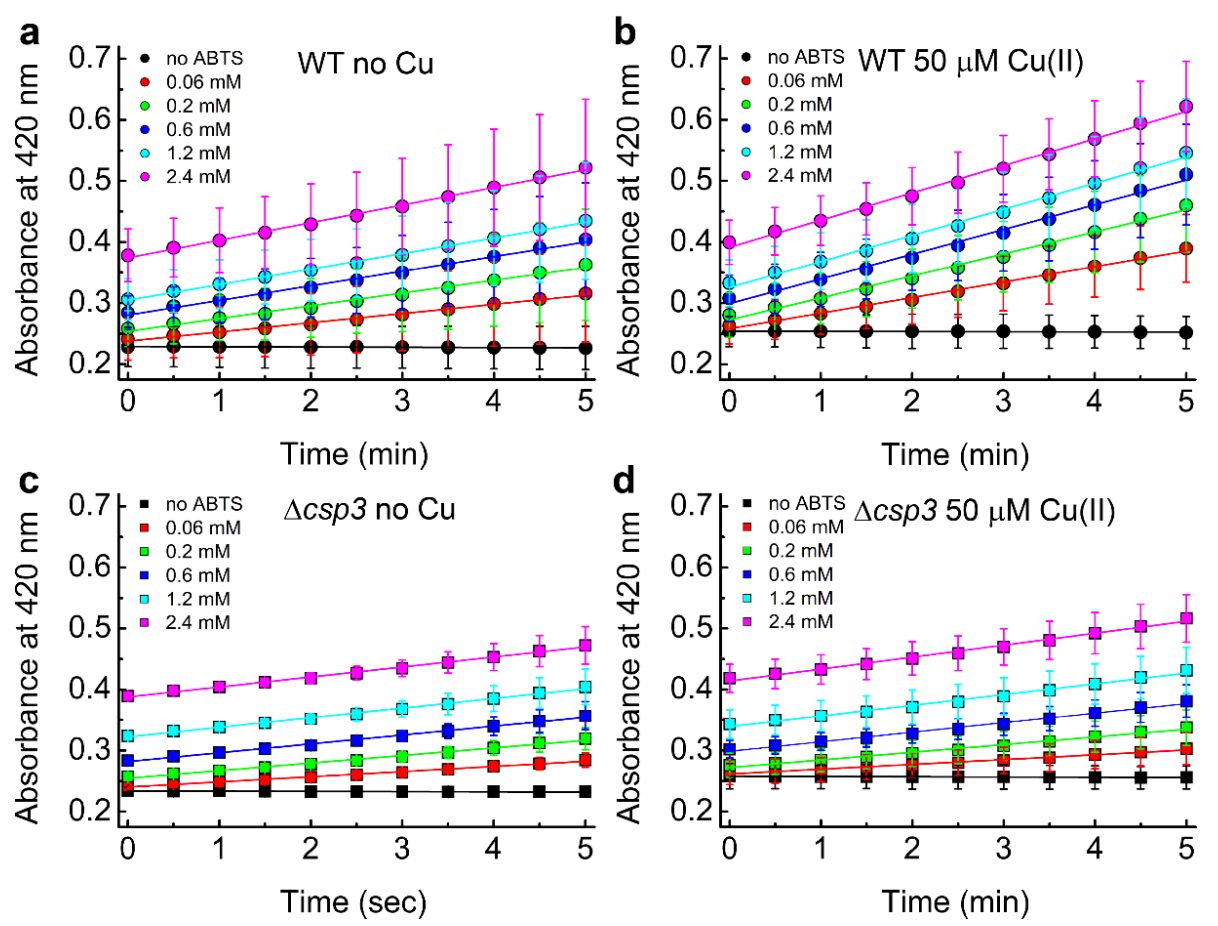

Supplementary Figure 3. The influence of Cu levels and deleting the csp3 gene on BsCotA

592 activity in $B$. subtilis spores. Plots of absorbance at $420 \mathrm{~nm}$ against time at different

593 concentrations of ABTS (indicated) for spores from WT (a) and (b) and $\Delta \operatorname{csp} 3$ (c) and (d) B.

594 subtilis. The data in (a) and (c) are from spores obtained in DSM without added Cu, whilst $50 \mu \mathrm{M}$ $595 \mathrm{Cu}\left(\mathrm{NO}_{3}\right)_{2}$ was added for $(\mathrm{b})$ and $(\mathrm{d})$. The reactions with $\mathrm{ABTS}$ were measured in $100 \mathrm{mM}$ citratephosphate buffer $\mathrm{pH} 4.0$ and the initial rates (averages from three different sets of spores with error bars showing standard deviations) we used for Figure $2 a(\mathrm{WT})$ and $2 \mathrm{~b}(\Delta \operatorname{csp} 3)$. 

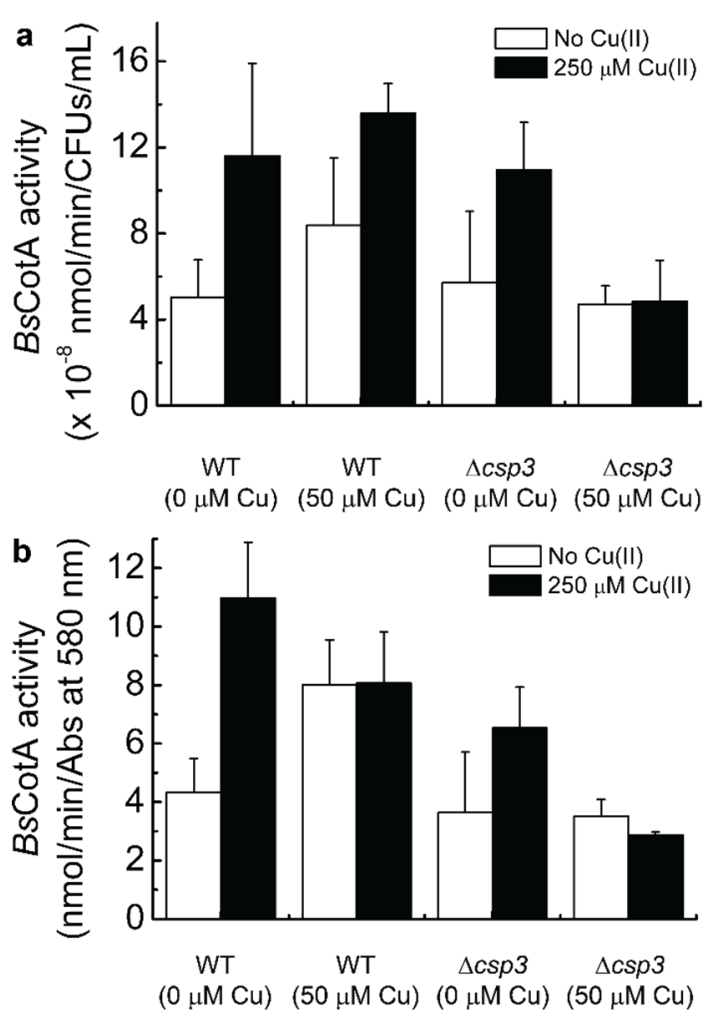

599 Supplementary Figure 4. Testing purified spores for enhanced BsCotA activity after incubation 600 with $\mathrm{Cu}(\mathrm{II})$. The influence of incubating spores in $250 \mu \mathrm{M} \mathrm{Cu}\left(\mathrm{NO}_{3}\right)_{2}$ from WT and $\Delta c s p 3 B$.

601 subtilis grown either in the absence or presence $(50 \mu \mathrm{M})$ of $\mathrm{Cu}\left(\mathrm{NO}_{3}\right)_{2}$ on their BsCotA activity.

602 The activity units are reported based on both CFU values (a) and the absorbance (Abs) at 580

$603 \mathrm{~nm}(\mathrm{~b})$ to quantify spores. Average values and standard deviations from three independent

604 experiments on the same spores used for the data in Figure 2a,b are shown, and the values are

605 listed in Supplementary Table 1. The reactions with ABTS were measured in $100 \mathrm{mM}$ citrate606 phosphate buffer $\mathrm{pH} 4.0$. 

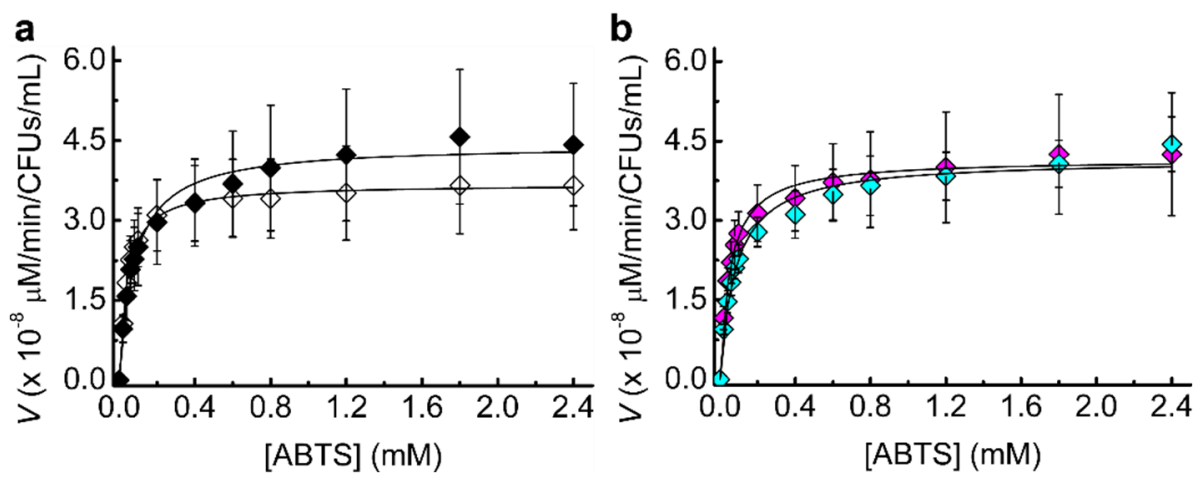

608

609

610

611

612

613

614

615

616

617

618

619

620

621

622

623

624

625

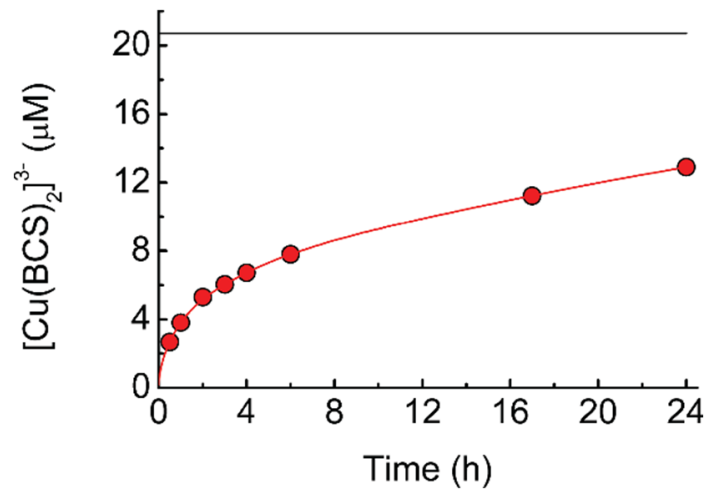

Supplementary Figure 5. The influence of Cu levels and IPTG on BsCotA activity in the control $\Delta c s p 3 B$. subtilis strain. Michaelis-Menten plots of BsCotA activity for heated purified spores from the control $\Delta c s p 3$ strain. (a) The analysis of spores produced in media plus 0 (open symbols) and 50 (black filled symbols) $\mu \mathrm{M}$ added $\mathrm{Cu}\left(\mathrm{NO}_{3}\right)_{2}$ with no added IPTG. (b) Data plus 1 mM IPTG and 0 (magenta) and 50 (cyan) $\mu \mathrm{M} \mathrm{Cu}\left(\mathrm{NO}_{3}\right)_{2}$. Averages and standard deviations from kinetic measurements in $100 \mathrm{mM}$ citrate-phosphate buffer $\mathrm{pH} 4.0$ using three different sets of spores are shown.

Time (h)

Supplementary Figure 6. The removal of $\mathrm{Cu}(\mathrm{I})$ from $\mathrm{BsCsp} 3$ by the high-affinity ligand $\mathrm{BCS}$. A plot of $\left[\mathrm{Cu}(\mathrm{BCS})_{2}\right]^{3-}$ concentration against time for BsCsp3 $(1.08 \mu \mathrm{M})$ plus 18.0 equivalents of $\mathrm{Cu}(\mathrm{I})$ mixed with $2.5 \mathrm{mM}$ BCS in $20 \mathrm{mM} \mathrm{HEPES} \mathrm{pH} 7.5$ plus $200 \mathrm{mM} \mathrm{NaCl}$ (red line). The data at $0.5,1,2,3,4,6,17$ and $24 \mathrm{~h}$, which correspond to times at which BsCotA activity was measured (Figure 4), are indicated by red circles. Average percentage removal compared to that for the unfolded samples, and the standard deviations, from three independent experiments are shown in Supplementary Table 2. The black line indicates the same experiment but with $6.64 \mathrm{M}$ guanidine- $\mathrm{HCl}$ present in the buffer. This helps unfold the protein and removal is much faster giving the end point for the reaction (the value shown was obtained after incubation for $2 \mathrm{~h}$ ). 

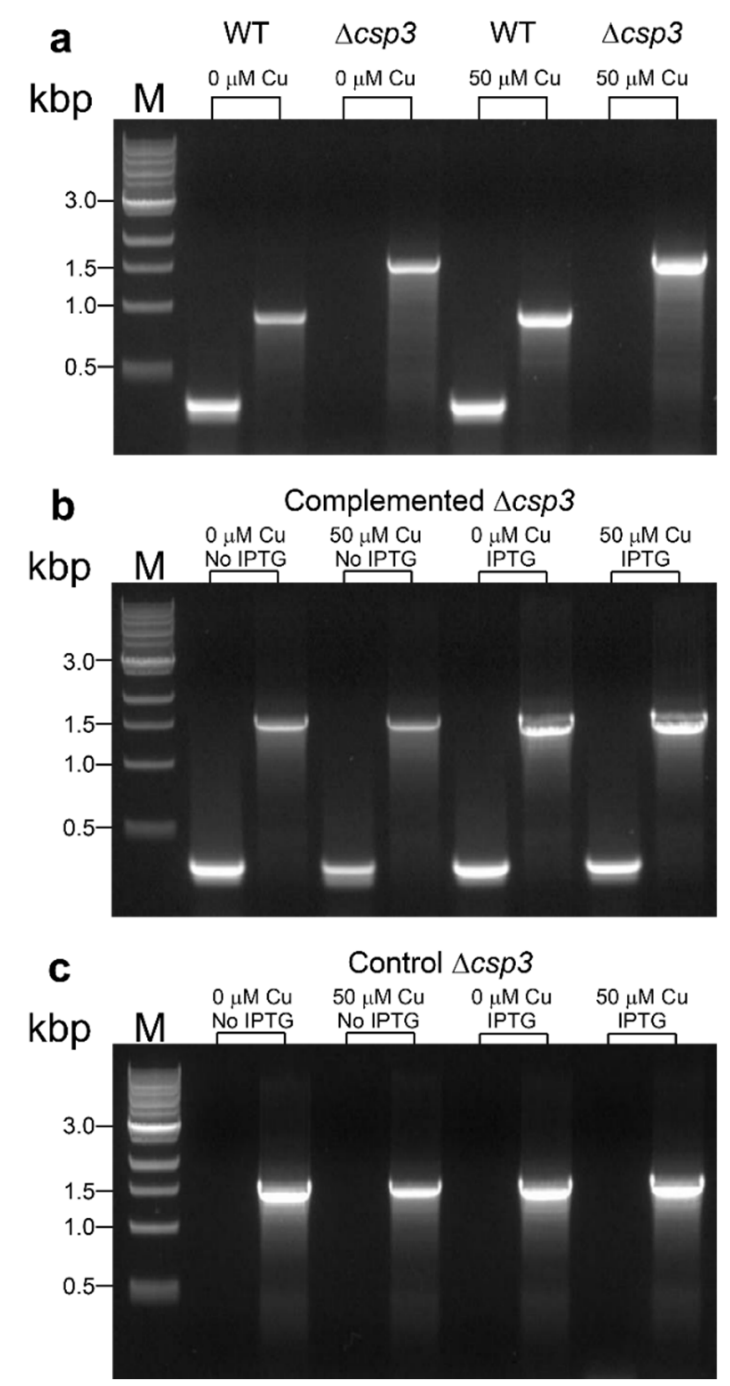

627 Supplementary Figure 7. PCR analyses of purified spore stocks from the $B$. subtilis strains

628 used in this study. (a) The rbs_BsCsp3-F and rbs_BsCsp3-R primers (Supplementary Table 3)

629 give a product of $373 \mathrm{bp}$ for the WT strain, whilst BsCsp3+300-F and BsCsp3+300-R give

630 fragments of 967 and 1663 bp for WT and $\Delta c s p 3$, respectively. (b) Re-introduction of the csp3

631 gene is confirmed in the complemented strain using the rbs_BsCsp3-F and rbs_BsCsp3-F

632 primers (as well as testing with BsCsp3+300-F and BsCsp3+300-R), and the same primers are

633 used to analyse the control $\Delta c s p 3$ strain (c). Analysis of spores used for the three independent

634 experiments on all four strains shown in Figure 2 and Supplementary Figure 5 gave the same

635 results. 
Supplementary Table 1. The influence of Cu concentration on the BsCotA activity of purified spores from WT and $\Delta \operatorname{csp} 3 B$. subtilis ${ }^{a}$

\begin{tabular}{|c|c|c|c|}
\hline \multirow[t]{2}{*}{ B. subtilis strain } & \multirow[t]{2}{*}{$\mathrm{Cu}(\mathrm{II})$ in media $^{b}$} & \multicolumn{2}{|c|}{ Spores incubated with } \\
\hline & & $250 \mu \mathrm{M} \mathrm{Cu}(\mathrm{II})$ & No $\mathrm{Cu}(\mathrm{II})$ \\
\hline & & \multicolumn{2}{|c|}{$\begin{array}{c}\text { BsCotA activity } \\
\mathrm{nmol} / \mathrm{min} / \mathrm{CFUs} / \mathrm{mL}\left(\times 10^{-8}\right)^{c}\end{array}$} \\
\hline WT & - & $11.6 \pm 4.29$ & $5.02 \pm 1.75$ \\
\hline WT & + & $13.6 \pm 1.37$ & $8.38 \pm 3.15$ \\
\hline$\Delta c s p 3$ & - & $11.0 \pm 2.20$ & $5.71 \pm 3.32$ \\
\hline \multirow[t]{2}{*}{$\Delta c s p 3$} & + & $4.84 \pm 1.92$ & $4.71 \pm 0.85$ \\
\hline & & \multicolumn{2}{|c|}{$\begin{array}{c}\text { BsCotA activity } \\
\mathrm{nmol} / \mathrm{min} / \mathrm{Abs} \text { at } 580 \mathrm{~nm}^{d}\end{array}$} \\
\hline WT & - & $11.0 \pm 1.90$ & $4.33 \pm 1.15$ \\
\hline WT & + & $8.07 \pm 1.76$ & $8.00 \pm 1.55$ \\
\hline$\Delta c s p 3$ & - & $6.53 \pm 1.40$ & $3.64 \pm 2.07$ \\
\hline$\Delta c s p 3$ & + & $2.87 \pm 0.11$ & $3.52 \pm 0.57$ \\
\hline
\end{tabular}

638

a Average values and standard deviations from the three independently grown sets of spores, used for the data in Figure 2a,b are shown (activity measurements measured in $100 \mathrm{mM}$ citratephosphate buffer $\mathrm{pH} 4.0$ ). ${ }^{b}$ The minus sign indicates that $\mathrm{Cu}$ was not added to media during sporulation, whilst the plus sign indicates that the DSM was supplemented with $50 \mu \mathrm{M} \mathrm{Cu}\left(\mathrm{NO}_{3}\right)_{2}$. $c$ Values used for Supplementary Figure $4 a$ with the numbers of spores calculated using CFUs. ${ }^{d}$ Data shown in Supplementary Figure $4 \mathrm{~b}$ and calculated by quantifying spores in suspensions using the absorbance (Abs) at $580 \mathrm{~nm}$, to enable direct comparison with a previous study (26). The data for WT B. subtilis are very similar to those in the earlier work (26), even though in that case $250 \mu \mathrm{M} \mathrm{Cu}(50 \mu \mathrm{M}$ here) was added to the DSM during sporulation. The only discrepancy is that previously (26), WT spores grown in the presence of Cu showed an approximate 2-fold decrease in activity upon incubation with $\mathrm{Cu}(\mathrm{II})$. This observation is difficult to explain, but the data reported in ref. 26 appears to be from a single replicate.

Supplementary Table 2. The removal of $\mathrm{Cu}(\mathrm{I})$ from BsCsp3 by BCS over time ${ }^{a, b}$

\begin{tabular}{cc}
\hline Time $(\mathrm{h})$ & \% Cu(I) removal $^{c}$ \\
\hline 0.5 & $12.9 \pm 0.54$ \\
1 & $18.0 \pm 0.71$ \\
2 & $24.7 \pm 1.33$ \\
3 & $28.3 \pm 1.23$ \\
4 & $31.5 \pm 1.39$ \\
6 & $36.6 \pm 1.50$ \\
17 & $52.9 \pm 2.31$ \\
24 & $60.7 \pm 2.35{ }^{d}$ \\
\hline
\end{tabular}

a Shown are the average percentage removal of $\mathrm{Cu}(\mathrm{I})$ from $\mathrm{BsCsp3}$ by $\mathrm{BCS}$ over time (and standard deviations) from three independent experiments. ${ }^{b}$ The amount of $\mathrm{Cu}(\mathrm{I})$ bound to the protein was determined by mixing the $\mathrm{Cu}(\mathrm{I})-\mathrm{BsCsp} 3$ sample with $2.5 \mathrm{mM} \mathrm{BCS}$ in the presence of $6.64 \mathrm{M}$ guanidine- $\mathrm{HCl}$ in $20 \mathrm{mM}$ HEPES $\mathrm{pH} 7.5$ plus $200 \mathrm{mM} \mathrm{NaCl}$, which unfolds the protein giving the maximum possible $\left[\mathrm{Cu}(\mathrm{BCS})_{2}\right]^{3-}$ concentration (the value used is after incubation for 2 h). ${ }^{c}$ Percentage $\mathrm{Cu}(\mathrm{I})$ removal is determined using $\left[\mathrm{Cu}(\mathrm{BCS})_{2}\right]^{3-}$ concentration/maximum $\left[\mathrm{Cu}(\mathrm{BCS})_{2}\right]^{3-}$ concentration $\times 100 .{ }^{d}$ On one occasion the experiment was analysed up to $48 \mathrm{~h}$ with $70 \% \mathrm{Cu}(\mathrm{I})$ removal observed. 
Supplementary Table 3. Primers used in this study

\begin{tabular}{|c|c|}
\hline Primers & Sequence \\
\hline BsCsp3+300-F a & 5'-CATTCATGACAGTGCGACG-3' \\
\hline BsCsp3+300-R a & 5'-CACAAGAGGACTGGACGC-3' \\
\hline BsCsp3_seq-F $b$ & 5'-CCGACAGCAGCAAATGCAGAAAACCA-3' \\
\hline BsCsp3_seq-R $b$ & 5'-AAACCGTCGACTTTTACTTGCG-3' \\
\hline rbs_BsCsp3-F ${ }^{c}$ & 5'-GGAGGACGCAAGCTTGCCGTGAAACATAAAACC-3' \\
\hline rbs_BsCsp3-R ${ }^{c}$ & 5'-GGAGGACGCGCTAGCTTACGCTGCCATGCTGCGGC-3' \\
\hline BsCsp3-F ${ }^{d}$ & 5'-GCGCATATGGAGCAATATTCTGAGGC-3' \\
\hline BsCsp3-R ${ }^{d}$ & 5'-GCGCCATGGTTACGCTGCCATGCTGCGGC-3' \\
\hline pDR111_int_Fe & 5'-GTGAACGCTCTCCTGAGTAG-3' \\
\hline pDR111_int_Re & 5'-GTCGGCTGAAAGATCGTAC-3' \\
\hline $\operatorname{Cot} \mathrm{A}-1 \mathrm{~F}^{f}$ & 5'-GGTCATATGACACTTGAAAAATTTGTGGATGC-3' \\
\hline $\operatorname{Cot} \mathrm{A}-1 \mathrm{R}^{f}$ & 5'-GGTGGATCCTTATTTATGGGGATCAGTTATATCC-3' \\
\hline CotA-2F $g$ & 5'-CATTGACTTCACAGCGTATGAAGGAGAATCG-3' \\
\hline CotA-2R $g$ & 5'-CGATTCTCCTTCATACGCTGTGAAGTCAATG-3' \\
\hline
\end{tabular}

661

662

663

664

665

666

667

668

669

670

671

672

673

a Forward and reverse primers designed to hybridise $\sim 300$ bp upstream and downstream of the csp3 gene giving PCR products of 1663 and 967 bp for $\Delta c s p 3$ and WT B. subtilis. ${ }^{b}$ Primers used to sequence the PCR product obtained from the $\Delta c s p 3$ strain using primers BsCsp3+300-F and BsCsp3+300-R. ${ }^{c}$ Forward (Hindlll site in bold) and reverse (Nhel site in bold, stop codon underlined) primers designed to amplify the csp3 gene plus $28 \mathrm{bp}$ at the 5 ' end to include its own RBS for cloning into pDR111. ${ }^{d}$ Forward and reverse primers that amplify the csp3 gene giving a PCR fragment of $345 \mathrm{bp}$ for WT B. subtilis. ${ }^{e}$ Primers that hybridise $294 \mathrm{bp}$ upstream and $118 \mathrm{bp}$ downstream of the region of pDR111 integrated into the amyE gene in the $B$. subtilis genome. For the complemented $\Delta c s p 3$ strain these give a $831 \mathrm{bp}$ fragment, whilst for the control $\Delta c s p 3$ strain the fragment size is $466 \mathrm{bp} .{ }^{f}$ Forward (Ndel site in bold) and reverse (BamHI site in bold, stop codon underlined) primers designed to amplify the cotA gene. ${ }^{g}$ Forward and reverse primers used to mutate the Ndel site (from CATATG to CATACG, highlighted in grey with the site mutation in bold) within the cotA gene. 